\title{
Genetic Profiling of Cancers of the Digestive System: Biological Insights and Clinical Implications
}

\author{
Albrecht Stenzinger $^{\mathrm{a}}$ Wilko Weichert ${ }^{\mathrm{b}}$ \\ anstitute of Pathology, University Hospital Heidelberg, Heidelberg, and ${ }^{\mathrm{b}}$ Institute of Pathology, Technical \\ University of Munich (TUM), and German Cancer Consortium (DKTK), Munich, Germany
}

\section{Keywords}

Genetic profiling · Cancer · Digestive system .

Next-generation sequencing · Biomarker · Drug target

\begin{abstract}
Massive parallel sequencing technologies (next-generation sequencing) have enabled us to draw a comprehensive landscape of the genomic aberrations underlying common cancers of the digestive system, and they have thus revolutionized our understanding of the genomic makeup and biology of these tumors. Apart from the commonly mutated founder genes, e.g., KRAS and TP53, we now have detailed information on additional and less frequent genomic events for every major digestive system cancer. However, many challenging issues remain when it comes to translating these findings into clinical applications. Recent examples are the precise definition of the role of genomic heterogeneity and tumor evolution in metastatic spread and their impact on oncologic therapy. Other unresolved issues include the usefulness of identified drivers as novel drug targets and predictive biomarkers, as well as the development of strategies to implement broad genomic testing in individualized patient care. This review aims to dissect and discuss these topics for selected major cancers.

(c) 2017 The Author(s)

Published by S. Karger AG, Basel
\end{abstract}

\section{KARGER}

E-Mail karger@karger.com www.karger.com/pat
(C) 2017 The Author(s)

Published by S. Karger AG, Basel

Karger

Open access

This article is licensed under the Creative Commons AttributionNonCommercial-NoDerivatives 4.0 International License (CC BYNC-ND) (http://www.karger.com/Services/OpenAccessLicense). Usage and distribution for commercial purposes as well as any distribution of modified material requires written permission.

\section{Introduction}

Carcinomas of the digestive system include a substantial variety of neoplasms ranging from esophageal cancer, gastric cancer (GC), small- and large-bowel cancers, and cancers of the anal region to cancers of the pancreas, liver, and bile duct system [1]. The overwhelming majority of these neoplasms are carcinomas (>90\%). Epidemiologically, overall more than 3.2 million cancer deaths per year worldwide can be attributed to these neoplasms. Digestive system malignancies account for approximately $40 \%$ of cancer-related deaths in both women and men worldwide and belong to a class of cancers that have a substantial impact in developed as well as developing countries [2]. This review briefly highlights the genetic underpinnings and clinical implications of these major cancer types and discusses biological concepts in and across these tumor entities.

Wilko Weichert, MD

Institute of Pathology

Technical University of Munich (TUM)

Trogerstrasse 18, DE-81275 Munich (Germany)

E-Mail wilko.weichert@tum.de

Albrecht Stenzinger, MD

Institute of Pathology

University Hospital Heidelberg

Im Neuenheimer Feld 224, DE-69120 Heidelberg (Germany)

E-Mail albrecht.stenzinger@ med.uni-heidelberg.de 


\section{The Genetic Landscape of Gastrointestinal Cancers}

\section{Colorectal Cancer}

Spearheaded by Vogelstein and colleagues [3-5], accumulating work on the genetics and genomics of colorectal cancer (CRC) has revealed a biological classification into 4 major molecular subtypes [6]: (1) nonhypermutated $\left(<8.24\right.$ mutations per $10^{6}$ bases, median: 58 nonsynonymous mutations) cancers with chromosomal instability (CIN) that are largely driven by mutations in KRAS as well as loss of heterozygosity in the tumor supressor genes APC and TP53; (2) hypermutated ( $>12$ mutations per $10^{6}$ bases, median: 728 nonsynonymous mutations) CRC comprising cancers with defective mismatch repair genes (either sporadic - often in conjunction with mutated $B R A F$ - or caused by germline events) resulting in microsatellite instability (MSI) and tumors with mutations mainly affecting the proofreading domain of the DNA polymerase POLE; (3) CRC characterized by the CpG island methylator phenotype (CIMP) showing a considerable overlap with microsatellite instable cancers and some nonhypermutated CRC; and (4) hypermutated and nonhypermutated cancers with genetic alterations in tetranucleotide repeats of microsatellites. These 4 groups are reflected by different morphological characteristics and clinical features. This holds particularly true for hypermutated CRC which present with a distinct phenotype (proximal colon, high tumor grade, mucinous differentiation, and strong immune response) and are associated with comparably good survival [7]. While these tumors appear to respond less well to 5-FU regimens [8], there is evidence that at least patients with MSI tumors benefit from novel immune modulatory drugs targeting the immune checkpoint response (for further details, see below) [9].

Interestingly, the mutational profile between nonhypermutated and hypermutated CRC is quite distinct except for $A P C$, which appears to be an important gatekeeper in both cancer types and highlights the important role of Wnt signaling for these cancers. While, besides KRAS (codons 12, 13, and 61) and TP53 mutations, nonhypermutated cases show frequent mutations in NRAS, another genetic component of MAPK signaling, and in PIK $3 C A$ as well as in genes encoding TGF- $\beta$ signaling components (e.g., $A C V R 1 B, S M A D 2$, and SMAD4), hypermutated cases are founded on genetic alterations of mismatch repair genes. In this context, biallelic hypermethylation of MLH1 is accountable for most sporadic cases $[10,11]$ and, as MLH1 can be one of the major methylation targets, there is a considerable overlap with CIMP-driven

Genetic Profiling of Sporadic Cancers of the Digestive System tumors [12]. Sporadic MSI-high tumors seem to accumulate mutations in genes containing intrinsic coding microsatellites (e.g., ACVR2, TGFBR2, MSH3, and MSH6) where especially frameshift mutations could lead to trunctated proteins that potentially serve as neoantigens for the immune system. Interestingly, though it does not harbor coding microsatellites, $B R A F$ is also a frequent target for mutations in sporadic MSI-H CRC. Missense and nonsense mutations affecting POLE [13] can lead to hypermutated tumors as well, which are, however, microsatellite stable (MSS).

In our view, probably the most intriguing finding of the major genetic and genomic profiling and functional studies is that - at least in sporadic CRC, which account for approximately $75 \%$ of all CRC - only very few genetic alterations are required to initiate and develop CRC (founder genes) and it is assumed that many of the other mutated genes are largely passengers that tag an individual CRC as a unique tumor but do not contribute much in terms of tumor biology $[14,15]$. However, we would like to point out that to our knowledge there is neither clinical nor experimental evidence that single rarely mutated genes do not contribute to shaping the biology of individual tumors. Hence, additional work is required to fully understand the functional contribution of the long tail of mutated genes in an individual context. Another important aspect we would like to highlight briefly in this context is derived from the discovery of these founder genes: as the term implies, these mutated genes are already apparent early in the development of colorectal neoplasms including clinically benign precursor lesions (e.g., frequent $B R A F$ mutations in preinvasive lesions of the serrated pathway including hyperplastic polyps [16]) so that detection of a mutated gene alone - without taking the biological and morphological context into consideration - is noninformative and could be heavily misleading in a clinical scenario if diagnostic and therapeutic decisions were solely based on this single parameter.

\section{Esophageal Cancer}

Esophageal squamous cell carcinoma (ESCC) has been the dominant esophageal cancer subtype worldwide for decades, but the incidence of esophageal adenocarcinoma (EAC) has increased over the last decades in Western countries. While these two cancer types require different oncological therapies and can be clinically challenging especially with advanced disease, the knowledge on the genetic aberrations underlying these tumors has been rather limited until recently. In 2013, besides identifying mutations in the tumor suppressors TP53 and CDKN2A as

Pathobiology 2017;84:306-322 DOI: $10.1159 / 000446545$ 
well as in SMAD4, ARID1A, and PIK3CA that had already been implicated in EAC earlier, Dulak et al. [17] reported on additional frequently mutated genes, including the chromatin-remodeling factors ARID1A, SMARCA4, ARID2, PBRM1, and JARID2, some of which had already been implicated in other major GI cancers. Moreover, they additionally identified mutations in genes that appear to modulate the invasion and motility of cancer cells. Among them ELMO1 and DOCK2, both of which encode dimerization partners and intracellular mediators of Rho familyGTPases, were the most frequently mutated genes. Two additional genes - SPG20 and TLR4 - that are functionally not well characterized yet but appear to play a role in tumorigenesis were also identified as significantly mutated genes. Other recurrently mutated genes included $A K A P 6$, the E3 ubiquitin ligase HECW1, and AJAP1, a gene mediating signaling at adherens junctions. Probably one of the most intriguing findings of a follow-up study conducted by Weaver et al. [18] was that even nondysplastic Barrett's esophagus (BE; established precursor lesion of EAC) showed mutations in cancer-associated genes, e.g., ARID1A and SMARCA4, while mutated TP53 and SMAD4 were mainly confined to BE with high-grade intraepithelial neoplasia. This study, which is conceptually based on previous single-gene studies investigating mutations in TP53 [19, 20], not only corroborates the role of mutant TP53 during neoplastic progression but it also extends the current knowledge of genetic lesions in $\mathrm{BE}$ with biological as well as putative diagnostic and clinical implications for the future. Hence, interrogation of these genes might be suitable to supplement conventional histology in the assessment of risk progression. Complementing these studies, Agrawal et al. [21], by comparing the genetic make-up of EAC and ESCC, showed that TP53 is the most commonly mutated gene in both cancer types and detected a considerable number of mutations in NOTCH1, NOTCH2, NOTCH3, and FBXW7 that were prevalent in ESCC. Three additional studies focusing on ESCC [22-24] confirmed the high prevalence of mutated TP53 and NOTCH1. The data regarding NOTCH1 point to the fact that this gene likely plays a role as a tumor supressor in ESCC, which is consistent with sequencing data of squamous cell carcinoma of the head and neck $[25,26]$, where NOTCH1 appears to play a similar role. Other major genetic themes in ESCC comprise frequent inactivation of cell cycle regulators (CDKN2A, CCND1 $R B 1$, and NFE2L2) as well as mutations in histone modifiers (e.g., ASHL1, MLL2, MLL3, and SETD1) and genetic alterations affecting MAPK signaling, with mutated PIK3CA being the most prevalent event. Another recent large-scale profiling study from the Cancer Genome Atlas Research Network in principle confirmed these mutational profiles and additionally emphasized that both EAC as well as ESCC harbor frequent amplifications albeit with a differing profile. While CCND1 as well as SOX2 and TP63 amplifications were prevalent in ESCC, EAC were prone to develop ERBB2, VEGFA GATA4, and GATA6 amplifications in a considerable number of cases. This study also established three molecular distinct subgroups for ESCC and proved that EAC molecularly profiles very much resemble that of the CIN subtype in GC (see below) [27].

\section{Gastric Cancer}

Over the last decades, a number of mutated genes in GC have been identified, including $A P C, A T M, C D H 1$, CREBBP, CTNNB1, KMT2D, KRAS, TRRAP, MLL, MLL3, PIK3CA, SETBP1, and TP53, among others. The first whole exome sequencing (WES) study [28] on GC confirmed many of these data and additionally identified frequent inactivating mutations in ARIDIA encoding a member of the SWI-SNF chromatin remodeling family. Mutations frequencies varied according to biological subtypes, with ARID1A mutations being most prevalent in MSI-driven tumors, closely followed by tumors with $E B V$ infections. Following up on this work, Zhang et al. [29] provided supportive results for a crucial role of ARID1A in GC carcinogenesis and additionally identified mutations and deletions in FAT4. The authors concluded that these two genes may act as important tumor supressors that become inactivated during GC carcinogenesis. Moreover, similar to hepatocellular carcinoma (HCC) (see below), they detected mutations in two other chromatin remodeling genes, i.e., $M L L$ and $M L L 3$. A year earlier, this group had already shown [30] recurrent mutations in $M A P 2 K 4$, and gene fusions involving CDK12 and ERBB2 in GC. Employing whole genome sequencing (WGS), Wang et al. [31] refined the mutational landscape by adding MUC6, CTNNA2, GLI3, RNF43, and RHOA to the set of mutated genes in GC. Interestingly, mutations in the latter gene were specifically observed in diffuse-type but not in intestinal-type GC. Wong et al. [32] identified further mutations in genes encoding ephrins and components of the SLIT/ROBO signaling pathway.

Comprehensively summarizing and extending the previous work briefly highlighted above, the Cancer Genome Atlas Research Network [33] suggested dividing GC into 4 distinct biological subtyes: EBV-infected tumors, MSI-driven tumors, genomcially stable tumors, and tumors with a CIN phenotype. EBV GC harbor a spe-
308

Pathobiology 2017;84:306-322 DOI: $10.1159 / 000446545$
Stenzinger/Weichert 
cific transcriptional profile, which is modulated by methylation of the promotor regions of various tumor suppressors, with CDKN2A almost always being affected. Moreover, this tumor subtype is strongly enriched for recurrent PIK3CA mutations (80\%) as well as for mutations in ARIDIA (55\%) and BCOR (20\%) encoding for an antiapoptotic protein, while mutations in TP53 were rarely observed. Interestingly, these tumors also harbor recurrent amplifications of ERBB2 and genes located at chromosome 9p (JAK2, PD-L1, and PD-L2). In contrast, MSI tumors show elevated mutation rates and a higher rate of mutations in genes encoding oncogenic signaling proteins (ERBB3, PIK3CA, KRAS, NRAS, and PTEN). Interestingly, however, this tumor subtype did not harbor $B R A F$ mutations that are frequently observed in sporadic MSI-driven CRC. The third group, i.e., genomically stable GC, displayed mutations in RHOA or fusions involving RHO family GTPase-activating proteins and was enriched for the diffuse histological variant. Lastly, tumors with CIN showed high mutation rates in TP53 accompanied by marked aneuploidy with focal amplification of receptor tyrosine kinases and cell cycle regulators (VEGFA, CCNE1, CCND1, and CDK6).

Finally, recent work from Cristescu et al. [34] that was mainly based on transcriptional profiling but also employed targeted sequencing and SNP arrays described 4 molecular subtypes that correlated with clinicopathological parameters including survival. Briefly, they identified 2 major classes of GC: MSI-driven tumors and MSS tumors. MSS tumors were further classified according to TP53 activity status and the presence/absence of an EMT signature. Applying this classifier to their cohort, they found that patients harboring GC of the MSI subtype had the best prognosis, while MSS tumors showing the EMT signature were associated with a dismal survival. They were able to substantiate their results by utilizing data of 3 independent studies for validation. Taken together, these data indicate that, while all of these studies provided great insight into the genetics of GC tumors, we now have to funnel resources to precisely understand the true biological impact of these findings and translate the results into novel therapies that benefit patients.

\section{Hepatocellular Carcinoma}

Over the last couple of years several major studies [3539] have confirmed long-known but also identified new genetic themes in HCC. Among them, recurrent mutations in CTNNB1 and AXIN1, as well as in CDKN2A, TP53, ATM, and IRF2 indicate that $\mathrm{Wnt} / \beta$ catenin signaling and impaired cell cycle regulation are

Genetic Profiling of Sporadic Cancers of the Digestive System the main drivers of HCC carcinogenesis. Other emerging themes are functional perturbation of chromatin remodeling genes (ARID1A and ARID2), recurrently mutated genes involved in acetylation and methylation of nucleosomes ( $M L L, M L L 2, M L L 3, M L L 4)$, and functional activation of the NFE2L2/KEAP1-mediated signaling cascade, respectively.

In addition, activating mutations in PIK3CA and inactivating mutations of RPS6KA3 point to a role for $\mathrm{PI} 3 \mathrm{~K} /$ Akt/mTOR signaling at least in some HCC. As reported by Kan et al. [38], a subset HCC with underlying HBV infection harbor activating mutations of JAK1 (9\%), and Nault et al. [40] identified frequent mutations (59\%) in the promotor region of TERT that confer increased activity to telomerase reverse transcriptase. Interestingly, the same group very recently showed clonal integration of adenoassociated virus type 2 (AAV2) in known driver genes [41], such as CCNA2, CCNE1, and TERT, among others, opening up another chapter of our understanding of HCC development. These data are in line with reports describing HBV insertions in TERT and MLL4, respectively [42, 43]. While the precise functional role of many of these genetic aberrations and in particular for mutated genes that execute epigenetic regulation, as well as for alterations in the NRF2/KEAP1 pathway involved in the cellular oxidative stress response, remains to be explored in the next years, these data provide important insights into HCC carcinogenesis that will hopefully be clinically exploitable in the near future. In this context, the aforementioned studies and in addition the recent discovery of unique and highly recurrent DNAJB1-PRKACA fusions in fibrolamellar HCC [44] convey an important message: it is crucial to consider the different etiologies of HCC and distinct phenotypes/rare subtypes to obtain a truly comprehensive and detailed landscape of genetic aberrations and their associations with clinical parameters. This applies to HCC in particular but can be deduced as a general concept to which all cancer profiling studies should ideally adhere.

\section{Cholangiocarcinoma}

Besides mutations in canonical genes implicated in other malignancies of the digestive system (KRAS, TP53, and $C D K N 2 A$ ), a recent study investigating intrahepatic cholangiocarcinoma (ICC) detected additional mutations in genes belonging to the family of chromatin-modifying genes (ARID1A, BAP1, and PBRM1;10-20\%) [45]. In addition, confirming previous studies, frequent mutations in IDH1 and IDH2 (20\%) were detected in the same group of tumors, and the discovery of mutated FGFR2 matches more recent data describing recurrent FGFR2-PPHLN1

Pathobiology 2017;84:306-322 DOI: $10.1159 / 000446545$ 
fusions [46]. As discussed further below, these genetic aberrations appear to be clinically exploitable. The latter study also described mutations in the ARAF oncogene, whose precise function in this biological context remains to be explored. Both studies reported recurrent mutations in genes encoding PIK3-AKT and MAPK signaling (KRAS, NRAS, PIK3CA, PIK3C2G, PIK3C2A, and PTEN), underscoring the importance of these pathways in the development of cholangiocarcinoma (CC). Jiao et al. [45] investigated 2 very small sets of gallbladder cancers and found mutated TP53 to be the most prevalent genetic aberration, followed by mutations in the chromatin-remodeling genes ARID1A, BAP1, MLL3, and PBRM1. While the latter findings appear to recapitulate the genetic landscape of HCC and CC of the bile ducts, the high frequency of TP53 mutations may point to the fact that, while there are common genetic themes shared across these cancer subtypes, clearly distinct genetic aberrations may propel and contribute to the different biological behavior. In addition, 2 studies investigating fluke-related CC [47, 48] identified a particularly high rate of TP53 mutations in these tumors and, by comparing these sequencing data with non-fluke-related CC, Chan-On et al. [47] concluded that these two tumor types show a reciprocal mutational pattern whereby mutations in chromatin modifiers as well as in IDH1 and IHD2 were much more prevalent in nonfluke-related tumors while TP53 mutations were much more common in fluke-related CC. These results emphasize that the analysis of cancer subtypes including different etiological contexts is paramount to truly understand the genetic basis of apparently homogenous tumor entities, and further genetic studies comprehensively dissecting CC subtypes are warranted.

\section{Pancreatic Cancer}

Pancreatic ductal adenocarcinoma (PDAC) is not only one of the deadliest cancer types but also still one of the most enigmatic malignancies for which novel effective treatment approaches are crucially required. With the data of recent molecular profiling efforts at hand, there is now a strong basis for future endeavors aimed at understanding the interplay of driver pathways and at developing drugs that will ultimately help to keep PDAC biology in check. In 2008, the pioneering work by Jones et al. [49] demonstrated a high prevalence of mutations in genes encoding KRAS signaling [50] which was in line with previous studies showing that mutated KRAS is a founder gene for PDAC that is already present in premalignant dysplastic lesions [51-55]. Besides KRAS, frequently mutated genes include TP53, CDKN2A, and SMAD4 - all well- known drivers of other major cancers of the digestive system. There is, however, a long tail of infrequently mutated genes contributing to the 12 core signaling pathways that were identified as active in PDAC by Jones et al. [49]. Subsequent work on metastatic PDAC [56, 57] identified a certain degree of genetic heterogeneity and subclonal branches that could be traced in the primary and metastatic lesions. Moreover, structural rearrangements ("fold back inversions") were identified that appear to be early events in PDAC development and may contribute to amplifications in the PDAC genome. In 2012, Biankin et al. [58] confirmed the high prevalence of mutations in KRAS as well as in the other canonical genes and also corroborated the presence of mutations across many genes at low frequencies. Interestingly, similar to HCC, they also detected mutations in genes that control epigenetic regulation of the genome (e.g., MLL3, ARID1A, EPC1, and ARID2), as well as in the DNA damage repair gene $A T M$. Moreover, they showed mutations in 5 genes whose functions in PDAC carcinogenesis are not well understood to date (ZIM2, MAP2K4, NALCN, SLC16A4, and MAGEA6). Spearheaded by Alexandrov et al. [59], analysis of mutational signatures across PDAC identified additional major mutagenic themes including activation of the APOBEC family of deaminases, $B R C A$ mediated DNA maintenance deficiency, and DNA mismatch repair deficiency. With additional efforts refining the aforementioned data [60-62], probably less than 10 major genetically perturbed pathways emerge that mainly contribute to the origin and development of PDAC and may be targetable to some extent: MAPK signaling, TGF- $\beta$ and Wnt signaling, cell cycle regulation, DNA damage response, and chromatin remodeling, as well as MYC- and NOTCH-driven signaling cascades.

\section{The Evolution of Clinical Genetic Testing in Tumors of the Digestive System}

After having briefly summarized the molecular landscapes of cancers of the digestive system (Fig. 1) and the tremendous impact of massive parallel sequencing (MPS) on our understanding of the genetic landscape and biology of these neoplasms, the second part of this review will focus on the implications of these novel insights for the clinical management of patients with cancers of the digestive system.

Among solid tumors including cancers of the digestive system, specifically CRC serves as a role model for the successful implementation of a specific genetic test that
310

Pathobiology 2017;84:306-322 DOI: $10.1159 / 000446545$
Stenzinger/Weichert 


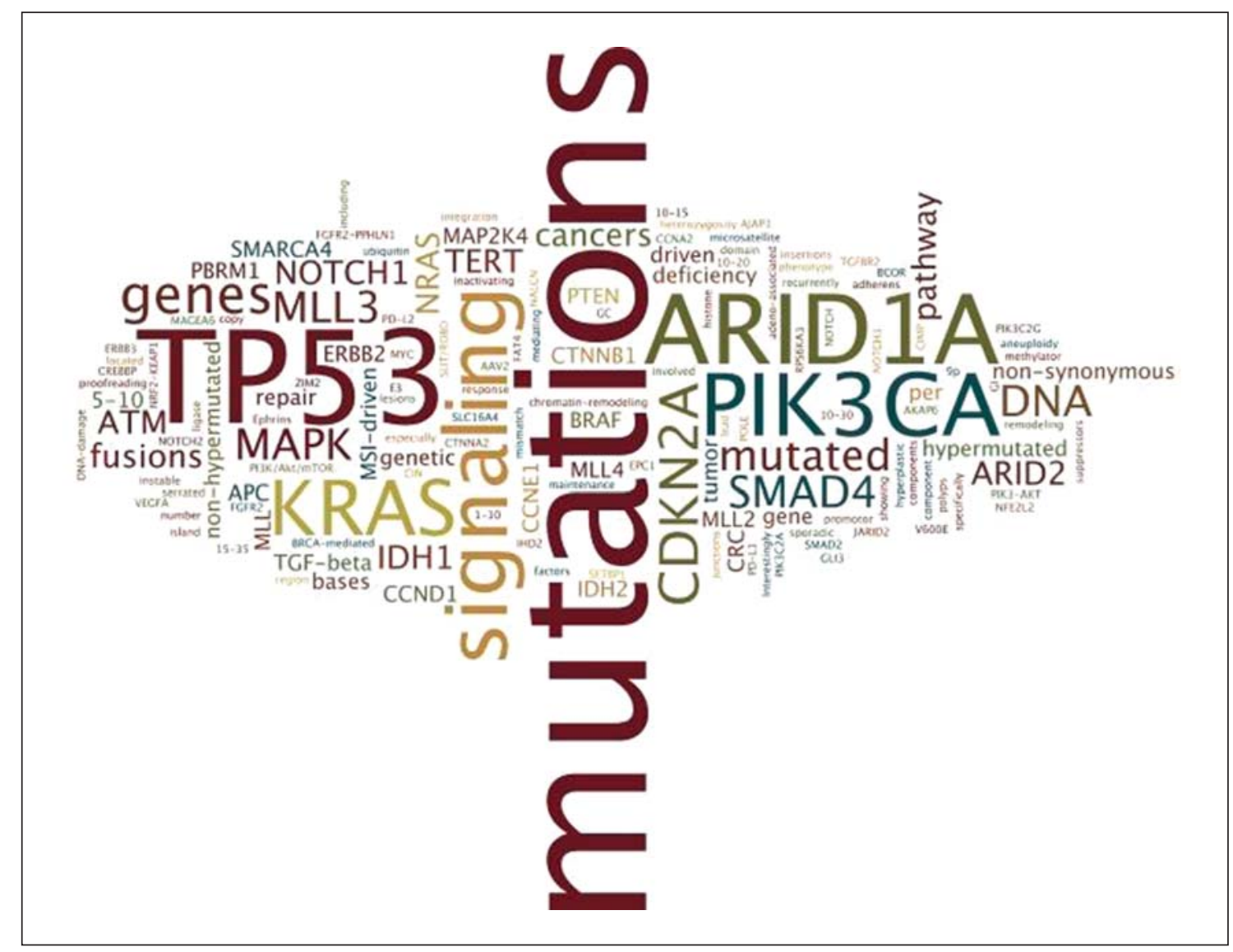

Fig. 1. Common molecular themes in cancers of the digestive system. Common frequently mutated driver genes across tumors of the gastrointestinal tract and the hepatopancreatic system.

governs treatment decisions. This pioneering work was triggered by observations that were made more than 10 years ago showing that patients with KRAS mutant CRC do not respond to EGFR targeting agents such as the monoclonal antibodies cetuximab $[63,64]$ and panitumumab [65]. These data subsequently led to a major change in the approval of these drugs by the European Medical Agency (EMA), which in 2008 demanded genetic testing of CRC for the presence of KRAS mutations as a prerequisite for antibody treatment. The reason for this decision was to yield a high level of patient benefit by balancing treatment efficacy and unwanted side effects. Of course, the dictum of the EMA also kept an eye on the development of health care costs, with molecular stratification influencing cost-benefit ratios in medical oncology. The overall success of this stratification approach, which can well be viewed as the advent of genetically informed personalized medicine in medical oncology, subsequently led to a refinement of this strategy via the addi-

Genetic Profiling of Sporadic Cancers of the Digestive System tion of less frequent mutations in other RAS genes to the panel of negative response predictors in the anti-EGFR setting [66]. In addition, mutations in other genes encoding downstream signal transducers of the MAPK cascade, such as $B R A F$, also appear to have a negative predictive value in MSS tumors [66]. These discoveries led to a change in the clinical guidelines for genetic testing, which now include a broad portfolio of alterations in RAS/RAF genes. Very recently, an analysis of several trials revealed that patients with KRAS-wildtype tumors show a different outcome when stratified into left-sided and right-sided tumors. Right-sided cancers are associated with a comparably poor prognosis, and it remains to be explored which molecular features govern the phenomenon of "sidedness" in CRC [67]. The second clinically established molecular stratifier in gastrointestinal malignancies constitutes Her2 expression as a positive response predictor for anti-ErbB2 drugs (such as trastuzumab) in GC [68]. Although measurement of expression levels of

Pathobiology 2017;84:306-322 311 


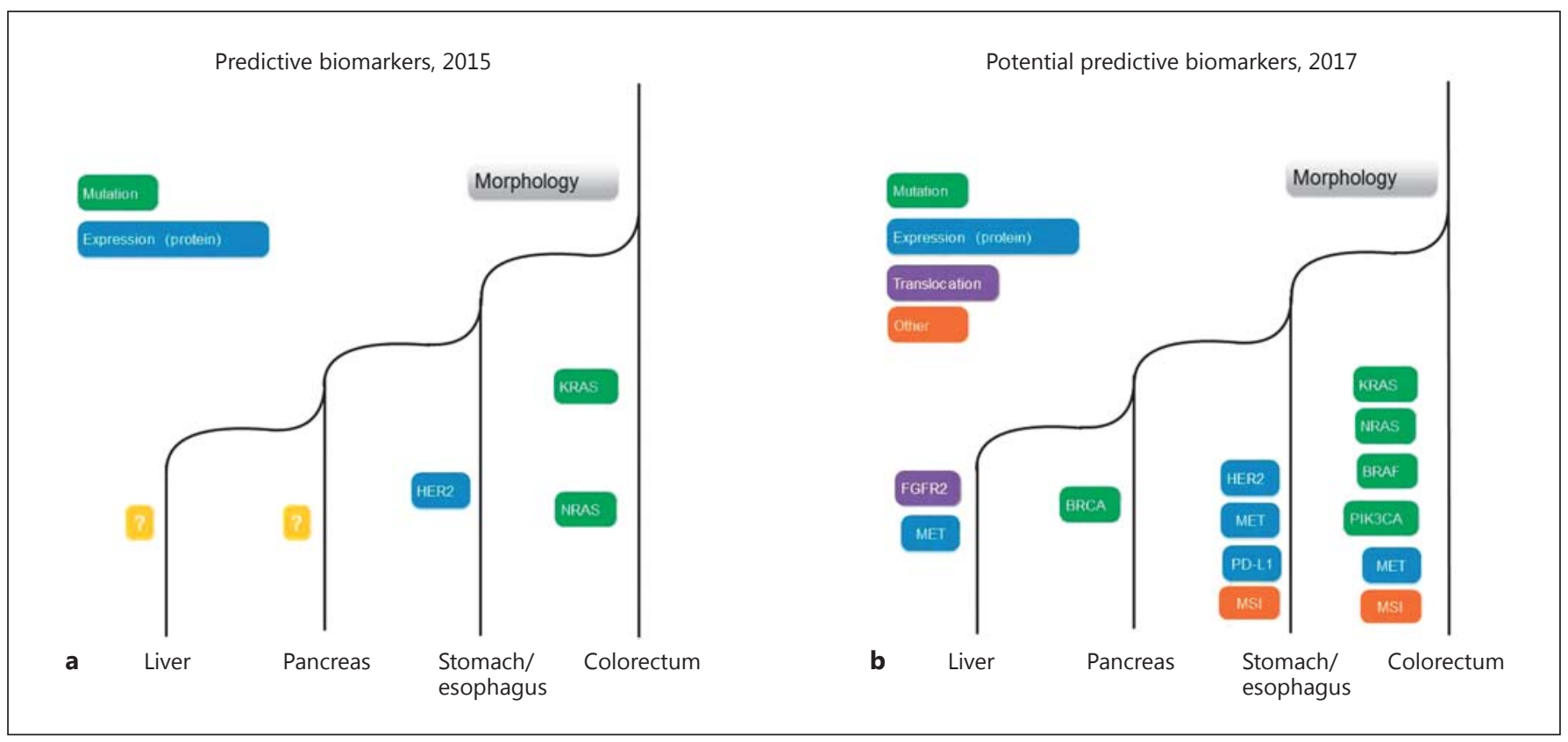

Fig. 2. Predictive molecular biomarkers in cancers of the digestive system. Current status of established (a) and potential future (b) molecular predictors in these cancers.

specific therapeutic targets by MPS technologies is not common practice for routine diagnostics yet, this situation may change in the near future when RNA sequencing techniques using formalin-fixed paraffin-embedded specimens become more widely available [69].

That being said, one could argue that while the application of MPS technologies is certainly interesting from a scientific point of view, there are still some obstacles on the road to clinical implementation. At first glance, a broad genomic characterization of cancers of the digestive system in the clinical setting may appear like cracking nuts with a sledgehammer as right now only RAS mutations in CRC are truly established response predictors (Fig. 2). However, the field is moving fast and new discoveries are being made at an accelerating speed [70]. First, a multitude of clinical studies are underway which are aimed at codiscovering predictive genetic targets together with effective novel targeted drug combinations [71] (see below) in almost all cancers of the digestive system. If only a fractal of these studies is successful, the current test approach will broaden tremendously with respect to both specific markers and the amount and types of cancers that require testing. Second, with prices for MPS continuously dropping, even for $R A S / R A F$ testing the cost-effectiveness turning point from conventional Sanger techniques to MPS is about to be reached [72]. Third, multigene test- ing for deselection of patients who will not benefit from a specific therapy has been shown to be cost-effective even in the setting of high test costs [73]. Finally, nowadays a variety of novel precision medicine approaches specifically aim to broadly stratifying patients to as yet nonapproved drugs/drug combinations as a final rescue attempt [74]. This applies in particular to last-line therapy settings in common tumor entities and to patients with rare tumors without firmly established therapy regimens.

\section{Genetic Heterogeneity of Tumors of the Digestive System and Its Clinical Implications}

In 1976, Peter Nowell, a pathologist and codiscoverer of the Philadelphia chromosome, published theoretical considerations on clonal evolution of cancers [75] which proved to be so farsighted and ahead of the curve that it took more than 30 years, and the evolution of several new technologies, for several groups to start to follow up on this concept experimentally and clearly demonstrate that cancers including solid malignancies are indeed composed of more than one cell clone. In 2008, Campbell et al. [76] provided evidence of subclonal diversity on the genetic level in B-CLL, and only 2 years later the 
same group [56] reported on the same phenomenon in PDAC with the demonstration of site-specific tumor cell branches. Similar data for PDAC were shown by Yachida et al. [57] the same year. Adding to this pioneering work, in 2012 Gerlinger et al. [77] contributed to the concept of genetic heterogeneity of tumors by demonstrating spatiotemporal genetic differences in clear cell renal cell cancer. Based on these landmark papers, the existence of competing cellular subclones and clonal evolution as measured by next-generation sequencing has emerged as an important topic in cancer research over the last couple of years. Several groups have even suggested that genetic tumor heterogeneity might explain why the success stories of biomarker discovery and identification of drug targets are modestly small to date [78-80]. The emerging picture is now that almost every major cancer of the digestive system, including CRC [81], PDAC [56], esophageal carcinoma and its precursors [82, 83], CC [84], and HCC [85], is composed of more than one tumor cell clone. The degree of genetic heterogeneity, however, appears to be quite variable. While the concept of tumor heterogeneity and the putative implications for tumor biology and therapy are exiting avenues of research worth following up on, and recent single-cell approaches will provide even more detailed insights into clonal diversity, in our view several open questions remain. First, most studies equate heterogeneity with genetic heterogeneity by definition, thereby largely ignoring the assessment of other molecular levels within tumor cells (e.g., proteome, transcriptome, and methylome), which could potentially contribute to tumor diversity. Second, based on these considerations, it becomes readily apparent that the heterogeneity of a tumor can be investigated on many levels [86] also including the histological phenotype and at various degrees of resolution which may lead to different or even divergent results according to the parameters analyzed. Third, although the evidence of genetic heterogeneity in cancers is compelling, the true functional consequences of many findings in terms of tumor biology and clinical behavior remain rather unclear. This applies in particular to genes that are mutated at low frequencies and whose functions including those of their wild-type counterparts remain to be discovered, but it also holds true for mutated major driver genes whose function and biological impact appear to be different according to their biological (genetic) context [70, 87-90]. Fourth, most studies including clinical trials have shown that founder mutations, which serve as prime targets for therapy or predictive biomarkers, are

Genetic Profiling of Sporadic Cancers of the Digestive System stable in primary tumors and their metastatic sites [9193]. In this context, a very recent perspective by Vogelstein and Kinzler [15] pointed out that a certain level of (genetic) heterogeneity will be present even in every normal tissue that is investigated and the really intriguing issue about cancer is possibly its peculiar genetic homogeneity rather than its heterogeneity. As pathologists, we encounter cases with varying degrees of tumor heterogeneity on a phenotypic level almost every day while viewing slides and signing out cases, and therefore we readily acknowledge the general concept of tumor evolution. The true biological and clinical significance of genetic heterogeneity for every specific tumor type, however, remains to be meticulously dissected and determined to avoid premature and possibly even misleading conclusions.

\section{Novel Modalities for Genomic Testing and Their Role in Tumors of the Digestive System}

With the first human genomes having been sequenced only about 15 years ago [94], it did not take long until the introduction of predictive genetic testing in routine tumor diagnostics [65]. Since then, an unprecedented development has taken place that has the potential to revolutionize oncology and pathology as we now know it. In the early days of genomic predictive tumor testing, the choice of methods was mainly among Sanger sequencing technologies, pyrosequencing, and allele-specific PCR methods, as exemplified for CRC [95]. However, when oligogene testing in lung cancer became the standard of molecular diagnostics about 5 years ago, molecular pathology laboratories began to explore the application of MPS technologies for genetic profiling of cancers in general using formalin-fixed paraffin-embedded material obtained from routine diagnostics. Initially many institutions focused on customized multigene panels [96-99] either with a one-fits-all approach or in an entity-tailored fashion as sequencing of whole exomes or even whole genomes in high-throughput routine diagnostics was (and still is) neither cost-effective nor efficient in terms of turnaround time. Additionally, technical difficulties with handling formalin-fixed paraffin-embedded and low-input amounts of DNA hampered broader sequencing approaches until now. However, with the advent of more sophisticated technologies that allow RNA and DNA sequencing even at single-cell resolution [100] and dropping costs, WES and WGS may become more widely available in routine diagnostic focus applications over

Pathobiology 2017;84:306-322 DOI: $10.1159 / 000446545$ 
time [101]. The big advantage of these approaches is that holding available specific up-to-date gene panels for different purposes and constant gene panel modifications and adoptions due to new discoveries would not be necessary anymore. Moreover, WES and WGS data could potentially be used to make true unbiased discoveries during routine diagnostics by comprehensive (pro- or retrospective) analysis of data sets. This applies not only to the discovery of the true prevalence of predictive and less frequent genetic aberrations in the own intention-totreat population but also to the detection of novel mutational patterns in subsets of major cancers as well as in rare tumors that may reshape diagnostic categories or will be clinically exploitable. Those data are needed from many centers on a national level and more ideally from around the world to establish a comprehensive database that provides an overview of mutational aberrations across all kinds of tumors and ideally links them to therapy response data [102]. While to some extent discovery by routine diagnostics can also be achieved by current targeted gene panels [96], this approach is certainly less powerful compared to WES/WGS. However, apart from technical considerations, the major challenge of all broad one-size-fits-all approaches is implementing a bioinformatics pipeline that obtains meaningful and valid results from WES and WGS data for routine diagnostics with a low turnaround time and at affordable costs.

That being said, it is nowadays evident that targeted sequencing approaches outperform conventional sequencing techniques in routine diagnostic molecular pathology [103]. In addition to the detection of simple somatic mutations, the technology can also be used to detect genetic macroaberrations such as copy number variations $[104]$ and gene fusions $[69,105]$ in routine diagnostics. With the technical issues regarding the implementation of targeted MPS in diagnostics being resolved, in our view issues of quality assurance [106] as well as reimbursement mark the last steps on the way to a broad use in routine molecular diagnostics across pathology centers.

\section{Novel Targetable Genetic Lesions in Cancers of the Digestive System}

Leaving molecular profiling for clinical trials aside [107], current molecular stratification approaches for the daily practice of cancer precision medicine mainly follow two roads. The first approach aims for a comprehensive molecular stratification of an individual tumor (e.g., in- cluding exomic/genomic, transcriptomic, and epigenomic data) and the subsequent application of individually selected - mostly off-label - therapies. However, these efforts are restricted to programs of selected major comprehensive cancer centers, and a broad application in routine diagnostics appears to not be feasible right now. A major challenge that lies ahead is that success stories derived from the current "individual patient" approach will likely remain on an anecdotal level unless large databases for cross-comparison of many individual data sets are established in order to fully understand the meaning of the clinical results.

The second approach aims for a step-by-step inclusion of novel single or oligomarker predictors for defined therapeutics in an entity-stratified manner. These marker-drug combinations have already been validated in a clinical study context and they have gained approval from the regulatory authorities. While a multitude of novel targeted drugs/marker combinations are currently being tested, Figure 2 provides a selection of the most relevant targets/markers for cancers of the digestive system that can be expected to enter the clinical arena in the next 2 years and which we will discuss in more detail below.

\section{Colorectal Cancer}

In CRC the focus in recent years has been on refinement of patient selection for anti-EGFR therapy. To this end, several novel biomarkers have been proposed, including PIK3CA mutations and others [66, 88, 108, 109]. A second class of drugs, which have been tested in a biomarker-selected population, comprise mutant-specific BRAF inhibitors. Although single agents or combinations with MEK inhibitors had been unsuccessful, preclinical modeling showed that combinations with EGFR inhibitors might be more promising. This led to clinical testing of this combination [87]. For another class of targeted agents - the antiangiogenic chemotherapeutics - active in CRC predictors of response have not yet been identified although major efforts have been directed toward this issue $[110,111]$. Apart from targeted agents, immune checkpoint inhibitors emerged as a new class of drugs that were designed to harness the immune system in the fight against cancer. A recent landmark study showed that specifically microsatellite instable CRC respond well to this therapeutic approach [9], presumably due to a higher mutational load of these tumors, which increases the likelihood of yielding novel immunogenic neoantigens [112]. From a molecular diagnostics point of view, the MSI status of CRC will therefore likely receive new attention that goes well beyond genetic counseling and
314

Pathobiology 2017;84:306-322

DOI: $10.1159 / 000446545$
Stenzinger/Weichert 
has direct therapeutic implications. While classic PCRbased assays will do the job, it would be desirable to implement MSI testing in current MPS approaches to ensure a one-stop shop. However, the direct interrogation of repetitive genomic sequences is still a major technical challenge in this context that needs to be resolved. A broader test approach potentially identifying all tumors with high mutational load regardless of the actual underlying cause (e.g., POLE mutations $[113,114]$ ) could be exome sequencing. Recent data also suggest that overall mutational load as surrogate marker for MSI status can also be infered from panel sequencing data [115]. Another approach could be the interrogation of frameshift mutations in specific genes known to be recurrently affected in MSI tumors. However, before implementation in routine diagnostics, additional data are needed to fully understand the relation between the efficacy of immune checkpoint inhibition and the mutational burden of different cancers.

\section{Gastric, Gastroesophageal, and Esophageal Cancer}

While gastric adenocarcinomas are usually lumped together with adenocarcinomas of the esophageogastral junction (AEG) and the esophagus, squamous cell carcinomas of the esophagus clearly constitute a molecularly and clinically distinct tumor entity. While for the latter, as for most squamous cell carcinomas, no convincing molecular predictors have been discovered so far, the former tumor entities obviously represent more accessible targets for novel chemotherapeutic treatment options [116]. This has been exemplified by the success of trastuzumab in Her2-positive gastric adenocarcinomas and AEG. Her2 targeting strategies are still being explored and expanded. In addition, MET has been identified as a promising targetable molecule in AEG and gastric adenocarcinomas overexpressing the protein [117]. VEGF targeting agents, which have also been recently identified as active in AEG and gastric adenocarcinomas, still come without any specific biomarker [118]. EGFR-inhibiting drugs have been tested for efficacy specifically in esophageal cancer, albeit without groundbreaking success to date [119]. As in CRC, immune checkpoint inhibitors might be effective in GC [120], and recent data indicate that MSI-driven tumors are likely to respond to this type of treatment [121]. As PD-L1 expression has been proposed as a response predictor for therapy with immune checkpoint blockers, patient selection will initially rely on straightforward PD-L1 IHC while the precise role of MSI analysis and mutational load assays remains to be determined.

Genetic Profiling of Sporadic Cancers of the Digestive System

\section{Liver Cancer and Pancreatic Cancer}

As already pointed out above, liver cancer is divided into HCC and CC, which in their own right are a group of molecularly quite divergent ICC and extrahepatic CC, with the latter bearing a strong molecular resemblance to PDAC.

Unfortunately, so far almost all strategies attacking HCC with targeted drugs have failed. Only the multikinase inhibitor sorafenib, showing a modest clinical response, has gained approval but, to date, no specific molecular predictive biomarkers have been identified for this drug $[122,123]$. One of the reasons for this continuous failure of targeted agents in HCC is a certain lack of druggable genes in these tumors. The two most promising drug/biomarker combinations currently being explored comprise MET inhibitors which appear to have a certain activity in MET-expressing HCC [124] and agents targeting FGF19 which was found to be amplified in a subset of HCC [125].

In principle, a similar situation exists for CC. Although we know the molecular landscape of both ICC and extrahepatic CC fairly well, none of the aberrations discovered has really emerged as a major drug target or could be used as a biomarker for treatment response so far. That being said, there may be some hope on the horizon as very recently recurrent gene fusions involving FGFR2 in ICC have been described [46], which are druggable targets. In this context, more recent data demonstrate that these tumors develop resistance mutations during treatment with FGFR inhibitors, an evolutionary phenomenon that is well known in lung cancers [126]. Another promising approach centers on the selection of CC with Her2 amplification/overexpression that appear to respond to antiHer2 treatment [127]. While current medical concepts still rely on conventional chemotherapeutic combinations [128], these two examples point towards a new direction in CC therapy.

PDAC is a tumor that is genetically founded on almost universally present undruggable KRAS mutations and has been shown to be resistant to a multitude of targeted therapies tested thus far [129]. So far, only erlotinib has been approved as a targeted agent but the survival advantage is minimal and no biomarker selection strategies have been identified for this drug to date [130]. The most promising potentially druggable family of molecular lesions, which can be observed in a small subset of PDAC, comprise mutated $B R C A 1$ and $B R C A 2$. Patients with mutations in these genes have been reported to respond to PARP inhibitory drugs in high-grade serous carcinoma of the ovary through a mechanism of synthetic lethality

Pathobiology 2017;84:306-322

DOI: $10.1159 / 000446545$ 


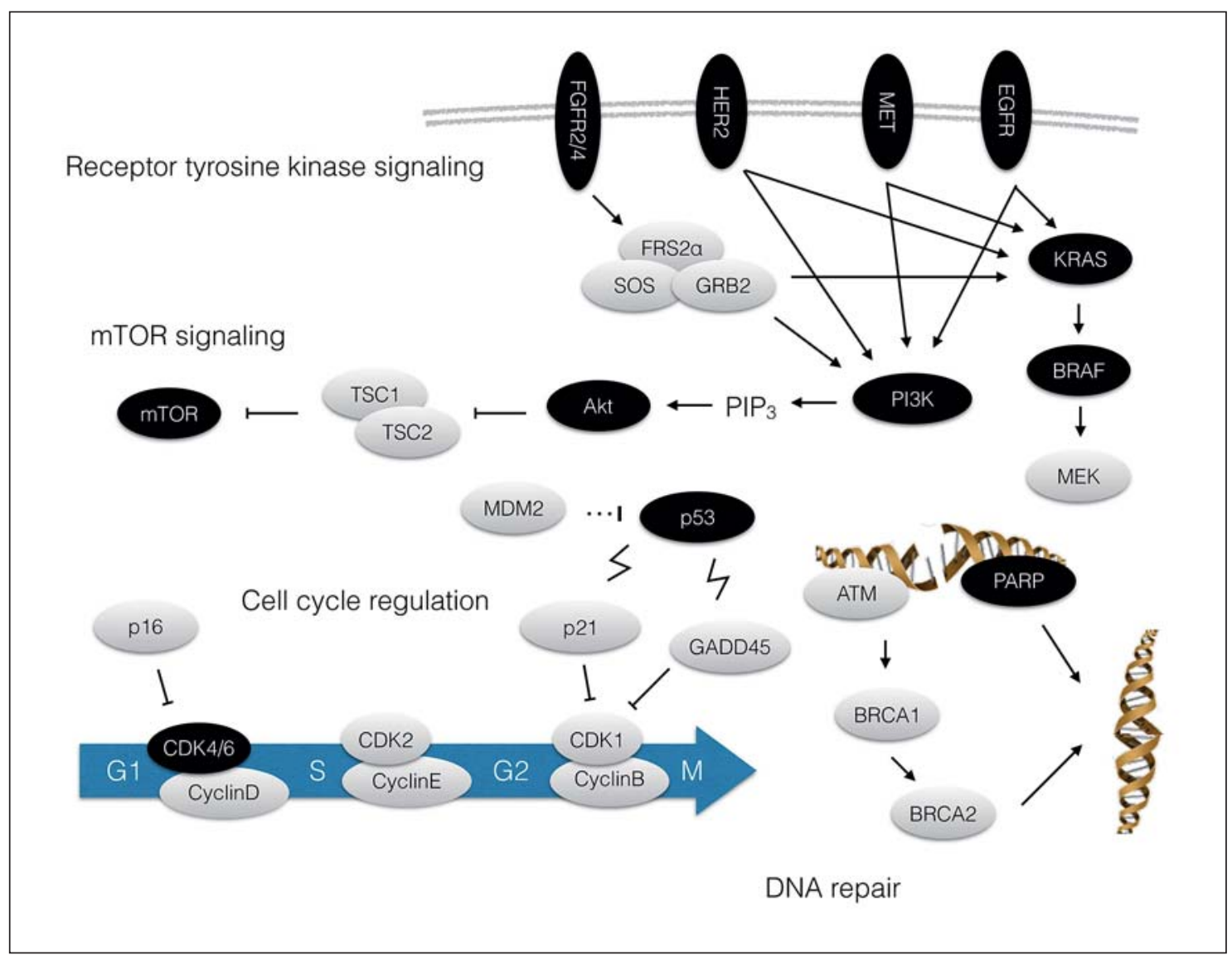

Fig. 3. Potential biomarkers and/or druggable mutations in cancers of the digestive system projected on oncogenic pathways. Target alterations in gastrointestinal and hepatopancreatic cancers are marked in black.

[131]. Preliminary data on very small PDAC patient populations indicate that this mode of action might also be true for pancreatic cancer [132], and it may well be that BRCAness and DNA repair deficiency in general are molecular themes that can be therapeutically exploited in specific subgroups of all digestive cancer types.

\section{Conclusion}

Over the last decade a multitude of efforts have led to the description of a fairly precise molecular landscape of gastrointestinal and hepatopancreatic cancers. However, many uncertainties (e.g., the prevalence and role of low-frequency mutations, gene fusions, specific genotype-phenotype associations, and rare tumor subtypes) prevail which define the need for further confirmation and - more importantly - extension of the published data sets. Also, still too little is known about the genetic hetero- geneity of these neoplasms and how precisely and to which extent genetic heterogeneity that is believed to fuel cancer evolution contributes to metastatic spread and relapse and interferes with current therapy approaches. Another line of research will be directed towards the genetic foundations of clinical response towards checkpoint blockers, including mutational load, MSI status, PD-L1 amplifications $[133,134]$, as well as putative resistance mutations $[135,136]$. Today, with many major technical challenges being resolved, a multitude of cancer centers implement at least targeted MPS technologies in routine diagnostics. In our view, with an arsenal of molecular profiling tools at hand, the real bottleneck and true challenge for therapy of cancers of the digestive system is now the identification of powerful genetic drug targets and biomarker combinations that benefit patients (Fig. 3). As outlined above, some - but still too few - are about to appear on the horizon and will be hopefully the beginning of a new era in the treatment of neoplasms of the digestive system (Fig. 2). 


\section{References}

1 WHO Classification of Tumours of the Digestive System, ed 4. Lyon, IACR Press, 2009.

2 Torre LA, Bray F, Siegel RL, Ferlay J, LortetTieulent J, Jemal A: Global cancer statistics, 2012. CA Cancer J Clin 2015;65:87-108.

3 Fearon ER, Vogelstein B: A genetic model for colorectal tumorigenesis. Cell 1990;61:759767.

4 Vogelstein B, Fearon ER, Hamilton SR, Kern SE, Preisinger AC, Leppert M, Nakamura Y, White R, Smits AM, Bos JL: Genetic alterations during colorectal-tumor development. N Engl J Med 1988;319:525-532.

5 Vogelstein B, Fearon ER, Kern SE, Hamilton SR, Preisinger AC, Nakamura Y, White R: Allelotype of colorectal carcinomas. Science 1989;244:207-211.

6 Zhang B, Wang J, Wang X, Zhu J, Liu Q, Shi Z, Chambers MC, Zimmerman LJ, Shaddox KF, Kim S, Davies SR, Wang S, Wang P, Kinsinger CR, Rivers RC, Rodriguez H, Townsend RR, Ellis MJ, Carr SA, Tabb DL, Coffey RJ, Slebos RJ, Liebler DC, Nci C: Proteogenomic characterization of human colon and rectal cancer. Nature 2014;513:382-387.

7 Popat S, Hubner R, Houlston RS: Systematic review of microsatellite instability and colorectal cancer prognosis. J Clin Oncol 2005; 23:609-618.

8 Ribic CM, Sargent DJ, Moore MJ, Thibodeau SN, French AJ, Goldberg RM, Hamilton SR, Laurent-Puig P, Gryfe R, Shepherd LE, Tu D, Redston M, Gallinger S: Tumor microsatellite-instability status as a predictor of benefit from fluorouracil-based adjuvant chemotherapy for colon cancer. N Engl J Med 2003;349: 247-257.

9 Le DT, Uram JN, Wang H, Bartlett BR, Kemberling $\mathrm{H}$, Eyring $\mathrm{AD}$, Skora $\mathrm{AD}$, Luber BS, Azad NS, Laheru D, Biedrzycki B, Donehower RC, Zaheer A, Fisher GA, Crocenzi TS, Lee JJ, Duffy SM, Goldberg RM, de la Chapelle A, Koshiji M, Bhaijee F, Huebner T, Hruban RH, Wood LD, Cuka N, Pardoll DM, Papadopoulos N, Kinzler KW, Zhou S, Cornish TC, Taube JM, Anders RA, Eshleman JR, Vogelstein B, Diaz LA Jr: Pd-1 blockade in tumors with mismatch-repair deficiency. N Engl J Med 2015;372:2509-2520.

10 Kane MF, Loda M, Gaida GM, Lipman J, Mishra R, Goldman H, Jessup JM, Kolodner R: Methylation of the hMLH1 promoter correlates with lack of expression of hMLH1 in sporadic colon tumors and mismatch repairdefective human tumor cell lines. Cancer Res 1997;57:808-811.

11 Herman JG, Umar A, Polyak K, Graff JR, Ahuja N, Issa JP, Markowitz S, Willson JK, Hamilton SR, Kinzler KW, Kane MF, Kolodner RD, Vogelstein B, Kunkel TA, Baylin SB: Incidence and functional consequences of hMLH1 promoter hypermethylation in colorectal carcinoma. Proc Natl Acad Sci USA 1998;95:6870-6875.
12 Weisenberger DJ, Siegmund KD, Campan M, Young J, Long TI, Faasse MA, Kang GH, Widschwendter M, Weener D, Buchanan D, Koh H, Simms L, Barker M, Leggett B, Levine J, Kim M, French AJ, Thibodeau SN, Jass J, Haile R, Laird PW: CpG island methylator phenotype underlies sporadic microsatellite instability and is tightly associated with BRAF mutation in colorectal cancer. Nat Genet 2006;38:787-793

13 Palles C, Cazier JB, Howarth KM, Domingo E, Jones AM, Broderick P, Kemp Z, Spain SL, Guarino E, Salguero I, Sherborne A, Chubb D, Carvajal-Carmona LG, Ma Y, Kaur K, Dobbins S, Barclay E, Gorman M, Martin L, Kovac MB, Humphray S; CORGI Consortium, WGS500 Consortium, Lucassen A, Holmes CC, Bentley D, Donnelly P, Taylor J, Petridis C, Roylance R, Sawyer EJ, Kerr DJ, Clark S, Grimes J, Kearsey SE, Thomas HJ McVean G, Houlston RS, Tomlinson I: Germline mutations affecting the proofreading domains of POLE and POLD1 predispose to colorectal adenomas and carcinomas. Nat Genet 2013;45:136-144.

14 Vogelstein B, Papadopoulos N, Velculescu VE, Zhou S, Diaz LA Jr, Kinzler KW: Cancer genome landscapes. Science 2013;339:15461558 .

15 Vogelstein B, Kinzler KW: The path to cancer - three strikes and you're out. N Engl J Med 2015;373:1895-1898.

16 Yang S, Farraye FA, Mack C, Posnik O, O'Brien MJ: BRAF and KRAS mutations in hyperplastic polyps and serrated adenomas of the colorectum: Relationship to histology and CpG island methylation status. Am J Surg Pathol 2004;28:1452-1459.

17 Dulak AM, Stojanov P, Peng S, Lawrence MS Fox C, Stewart C, Bandla S, Imamura Y, Schumacher SE, Shefler E, McKenna A, Carter SL, Cibulskis K, Sivachenko A, Saksena G, Voet D, Ramos AH, Auclair D, Thompson $\mathrm{K}$, Sougnez C, Onofrio RC, Guiducci C, Beroukhim R, Zhou Z, Lin L, Lin J, Reddy R, Chang A, Landrenau R, Pennathur A, Ogino S, Luketich JD, Golub TR, Gabriel SB, Lander ES, Beer DG, Godfrey TE, Getz G, Bass AJ: Exome and whole-genome sequencing of esophageal adenocarcinoma identifies recurrent driver events and mutational complexity. Nat Genet 2013;45:478-486.

18 Weaver JM, Ross-Innes CS, Shannon N, Lynch AG, Forshew T, Barbera M, Murtaza M, Ong CA, Lao-Sirieix P, Dunning MJ, Smith L, Smith ML, Anderson CL, Carvalho B, O'Donovan M, Underwood TJ, May AP, Grehan N, Hardwick R, Davies J, Oloumi A, Aparicio S, Caldas C, Eldridge MD, Edwards PA, Rosenfeld N, Tavare S, Fitzgerald RC; OCCAMS Consortium: Ordering of mutations in preinvasive disease stages of esophageal carcinogenesis. Nat Genet 2014;46:837843.
19 Bian YS, Osterheld MC, Bosman FT, Benhattar J, Fontolliet C: P53 gene mutation and protein accumulation during neoplastic progression in Barrett's esophagus. Mod Pathol 2001; 14:397-403.

20 Schneider PM, Casson AG, Levin B, Garewal HS, Hoelscher AH, Becker K, Dittler HJ, Cleary KR, Troster M, Siewert JR, Roth JA: Mutations of p53 in Barrett's esophagus and Barrett's cancer: a prospective study of ninety-eight cases. J Thorac Cardiovasc Surg 1996; 111:323-331, discussion 331-323.

21 Agrawal N, Jiao Y, Bettegowda C, Hutfless SM, Wang Y, David S, Cheng Y, Twaddell WS, Latt NL, Shin EJ, Wang LD, Wang L, Yang W, Velculescu VE, Vogelstein B, Papadopoulos N, Kinzler KW, Meltzer SJ: Comparative genomic analysis of esophageal adenocarcinoma and squamous cell carcinoma. Cancer Discov 2012;2:899-905.

22 Lin DC, Hao JJ, Nagata Y, Xu L, Shang L, Meng X, Sato Y, Okuno Y, Varela AM, Ding LW, Garg M, Liu LZ, Yang H, Yin D, Shi ZZ, Jiang YY, Gu WY, Gong T, Zhang Y, Xu X, Kalid O, Shacham S, Ogawa S, Wang MR, Koeffler HP: Genomic and molecular characterization of esophageal squamous cell carcinoma. Nat Genet 2014;46:467-473.

23 Song Y, Li L, Ou Y, Gao Z, Li E, Li X, Zhang W, Wang J, Xu L, Zhou Y, Ma X, Liu L, Zhao Z, Huang X, Fan J, Dong L, Chen G, Ma L, Yang J, Chen L, He M, Li M, Zhuang X, Huang K, Qiu K, Yin G, Guo G, Feng Q, Chen $\mathrm{P}, \mathrm{Wu} \mathrm{Z}, \mathrm{Wu}$ J, Ma L, Zhao J, Luo L, Fu M, Xu B, Chen B, Li Y, Tong T, Wang M, Liu Z, Lin D, Zhang X, Yang H, Wang J, Zhan Q: Identification of genomic alterations in oesophageal squamous cell cancer. Nature 2014;509: 91-95.

24 Gao YB, Chen ZL, Li JG, Hu XD, Shi XJ, Sun ZM, Zhang F, Zhao ZR, Li ZT, Liu ZY, Zhao YD, Sun J, Zhou CC, Yao R, Wang SY, Wang P, Sun N, Zhang BH, Dong JS, Yu Y, Luo M, Feng XL, Shi SS, Zhou F, Tan FW, Qiu B, Li N, Shao K, Zhang LJ, Zhang LJ, Xue Q, Gao SG, He J: Genetic landscape of esophageal squamous cell carcinoma. Nat Genet 2014;46: 1097-1102.

25 Agrawal N, Frederick MJ, Pickering CR, Bettegowda C, Chang K, Li RJ, Fakhry C, Xie TX, Zhang J, Wang J, Zhang N, El-Naggar AK, Jasser SA, Weinstein JN, Trevino L, Drummond JA, Muzny DM, Wu Y, Wood LD, Hruban RH, Westra WH, Koch WM, Califano JA, Gibbs RA, Sidransky D, Vogelstein B, Velculescu VE, Papadopoulos N, Wheeler DA, Kinzler KW, Myers JN: Exome sequencing of head and neck squamous cell carcinoma reveals inactivating mutations in NOTCH1. Science 2011;333:1154-1157. 
26 Stransky N, Egloff AM, Tward AD, Kostic AD, Cibulskis K, Sivachenko A, Kryukov V, Lawrence MS, Sougnez C, McKenna A, Shefler E, Ramos AH, Stojanov P, Carter SL, Voet D, Cortes ML, Auclair D, Berger MF, Saksena G, Guiducci C, Onofrio RC, Parkin M, Romkes M, Weissfeld JL, Seethala RR, Wang L, Rangel-Escareno C, FernandezLopez JC, Hidalgo-Miranda A, MelendezZajgla J, Winckler W, Ardlie K, Gabriel SB, Meyerson M, Lander ES, Getz G, Golub TR, Garraway LA, Grandis JR: The mutational landscape of head and neck squamous cell carcinoma. Science 2011;333:11571160.

27 Cancer Genome Atlas Research Network, et al: Integrated genomic characterization of oesophageal carcinoma. Nature 2017;541:169175.

28 Wang K, Kan J, Yuen ST, Shi ST, Chu KM, Law S, Chan TL, Kan Z, Chan AS, Tsui WY, Lee SP, Ho SL, Chan AK, Cheng GH, Roberts PC, Rejto PA, Gibson NW, Pocalyko DJ, Mao $\mathrm{M}, \mathrm{Xu}$ J, Leung SY: Exome sequencing identifies frequent mutation of ARID1A in molecular subtypes of gastric cancer. Nat Genet 2011; 43:1219-1223.

29 Zang ZJ, Cutcutache I, Poon SL, Zhang SL, McPherson JR, Tao J, Rajasegaran V, Heng HL, Deng N, Gan A, Lim KH, Ong CK, Huang D, Chin SY, Tan IB, Ng CC, Yu W, Wu Y, Lee M, Wu J, Poh D, Wan WK, Rha SY, So J, Salto-Tellez M, Yeoh KG, Wong WK, Zhu YJ, Futreal PA, Pang B, Ruan Y, Hillmer AM, Bertrand D, Nagarajan N, Rozen S, Teh BT, Tan P: Exome sequencing of gastric adenocarcinoma identifies recurrent somatic mutations in cell adhesion and chromatin remodeling genes. Nat Genet 2012;44:570-574.

30 Zang ZJ, Ong CK, Cutcutache I, Yu W, Zhang SL, Huang D, Ler LD, Dykema K, Gan A, Tao J, Lim S, Liu Y, Futreal PA, Grabsch H, Furge KA, Goh LK, Rozen S, Teh BT, Tan P: Genetic and structural variation in the gastric cancer kinome revealed through targeted deep sequencing. Cancer Res 2011;71:29-39.

31 Wang K, Yuen ST, Xu J, Lee SP, Yan HH, Shi ST, Siu HC, Deng S, Chu KM, Law S, Chan KH, Chan AS, Tsui WY, Ho SL, Chan AK, Man JL, Foglizzo V, Ng MK, Chan AS, Ching YP, Cheng GH, Xie T, Fernandez J, Li VS, Clevers $\mathrm{H}$, Rejto PA, Mao M, Leung SY: Wholegenome sequencing and comprehensive molecular profiling identify new driver mutations in gastric cancer. Nat Genet 2014;46: 573-582.

32 Wong SS, Kim KM, Ting JC, Yu K, Fu J, Liu S, Cristescu R, Nebozhyn M, Gong L, Yue YG, Wang J, Ronghua C, Loboda A, Hardwick J, Liu X, Dai H, Jin JG, Ye XS, Kang SY, Do IG, Park JO, Sohn TS, Reinhard C, Lee J, Kim S, Aggarwal A: Genomic landscape and genetic heterogeneity in gastric adenocarcinoma revealed by whole-genome sequencing. Nat Commun 2014;5:5477.
33 Cancer Genome Atlas Research Network: Comprehensive molecular characterization of gastric adenocarcinoma. Nature 2014;513: 202-209.

34 Cristescu R, Lee J, Nebozhyn M, Kim KM, Ting JC, Wong SS, Liu J, Yue YG, Wang J, Yu K, Ye XS, Do IG, Liu S, Gong L, Fu J, Jin JG, Choi MG, Sohn TS, Lee JH, Bae JM, Kim ST, Park SH, Sohn I, Jung SH, Tan P, Chen R, Hardwick J, Kang WK, Ayers M, Hongyue D, Reinhard C, Loboda A, Kim S, Aggarwal A: Molecular analysis of gastric cancer identifies subtypes associated with distinct clinical outcomes. Nat Med 2015;21:449-456.

35 Guichard C, Amaddeo G, Imbeaud S, Ladeiro Y, Pelletier L, Maad IB, Calderaro J, BioulacSage P, Letexier M, Degos F, Clement B, Balabaud C, Chevet E, Laurent A, Couchy G, Letouze E, Calvo F, Zucman-Rossi J: Integrated analysis of somatic mutations and focal copy-number changes identifies key genes and pathways in hepatocellular carcinoma. Nat Genet 2012;44:694-698.

36 Fujimoto A, Totoki Y, Abe T, Boroevich KA, Hosoda F, Nguyen HH, Aoki M, Hosono N, Kubo M, Miya F, Arai Y, Takahashi H, Shirakihara T, Nagasaki M, Shibuya T, Nakano K, Watanabe-Makino K, Tanaka H, Nakamura $\mathrm{H}$, Kusuda J, Ojima H, Shimada K, Okusaka T, Ueno M, Shigekawa Y, Kawakami Y, Arihiro K, Ohdan H, Gotoh K, Ishikawa O, Ariizumi S, Yamamoto M, Yamada T, Chayama K, Kosuge T, Yamaue H, Kamatani N, Miyano $S$, Nakagama $H$, Nakamura $Y$, Tsunoda T, Shibata T, Nakagawa H: Whole-genome sequencing of liver cancers identifies etiological influences on mutation patterns and recurrent mutations in chromatin regulators. Nat Genet 2012;44:760-764.

37 Huang J, Deng Q, Wang Q, Li KY, Dai JH, Li N, Zhu ZD, Zhou B, Liu XY, Liu RF, Fei QL, Chen H, Cai B, Zhou B, Xiao HS, Qin LX, Han $Z G$ : Exome sequencing of hepatitis $B$ virusassociated hepatocellular carcinoma. Nat Genet 2012;44:1117-1121.

38 Kan Z, Zheng H, Liu X, Li S, Barber TD, Gong Z, Gao H, Hao K, Willard MD, Xu J, Hauptschein R, Rejto PA, Fernandez J, Wang G, Zhang Q, Wang B, Chen R, Wang J, Lee NP, Zhou W, Lin Z, Peng Z, Yi K, Chen S, Li L, Fan X, Yang J, Ye R, Ju J, Wang K, Estrella H, Deng S, Wei P, Qiu M, Wulur IH, Liu J, Ehsani ME, Zhang C, Loboda A, Sung WK, Aggarwal A, Poon RT, Fan ST, Wang J, Hardwick J, Reinhard C, Dai H, Li Y, Luk JM, Mao M: Wholegenome sequencing identifies recurrent mutations in hepatocellular carcinoma. Genome Res 2013;23:1422-1433.

39 Cleary SP, Jeck WR, Zhao X, Chen K, Selitsky SR, Savich GL, Tan TX, Wu MC, Getz G, Lawrence MS, Parker JS, Li J, Powers S, Kim H, Fischer S, Guindi M, Ghanekar A, Chiang DY: Identification of driver genes in hepatocellular carcinoma by exome sequencing. Hepatology 2013;58:1693-1702.

40 Nault JC, Mallet M, Pilati C, Calderaro J, Bioulac-Sage $P$, Laurent $C$, Laurent A, Cherqui D,
Balabaud C, Zucman-Rossi J: High frequency of telomerase reverse-transcriptase promoter somatic mutations in hepatocellular carcinoma and preneoplastic lesions. Nat Commun 2013;4:2218.

41 Nault JC, Datta S, Imbeaud S, Franconi A, Mallet M, Couchy G, Letouze E, Pilati C, Verret B, Blanc JF, Balabaud C, Calderaro J, Laurent A, Letexier M, Bioulac-Sage P, Calvo F, ZucmanRossi J: Recurrent AAV2-related insertional mutagenesis in human hepatocellular carcinomas. Nat Genet 2015;47:1187-1193.

42 Dong H, Zhang L, Qian Z, Zhu X, Zhu G, Chen Y, Xie X, Ye Q, Zang J, Ren Z, Ji Q: Identification of HBV-MLL4 integration and its molecular basis in Chinese hepatocellular carcinoma. PLoS One 2015; 10:e0123175.

43 Ding D, Lou X, Hua D, Yu W, Li L, Wang J, Gao F, Zhao N, Ren G, Li L, Lin B: Recurrent targeted genes of hepatitis $B$ virus in the liver cancer genomes identified by a next-generation sequencing-based approach. PLoS Genet 2012;8:e1003065.

44 Honeyman JN, Simon EP, Robine N, ChiaroniClarke R, Darcy DG, Lim II, Gleason CE, Murphy JM, Rosenberg BR, Teegan L, Takacs CN, Botero S, Belote R, Germer S, Emde AK, Vacic V, Bhanot U, LaQuaglia MP, Simon SM: Detection of a recurrent DNAJB1-PRKACA chimeric transcript in fibrolamellar hepatocellular carcinoma. Science 2014;343:1010-1014.

45 Jiao Y, Pawlik TM, Anders RA, Selaru FM, Streppel MM, Lucas DJ, Niknafs N, Guthrie VB, Maitra A, Argani P, Offerhaus GJ, Roa JC, Roberts LR, Gores GJ, Popescu I, Alexandrescu ST, Dima S, Fassan M, Simbolo M, Mafficini A, Capelli P, Lawlor RT, Ruzzenente A, Guglielmi A, Tortora G, de Braud F, Scarpa A, Jarnagin W, Klimstra D, Karchin R, Velculescu VE, Hruban RH, Vogelstein B, Kinzler KW, Papadopoulos $\mathrm{N}$, Wood LD: Exome sequencing identifies frequent inactivating mutations in BAP1, ARID1A and PBRM1 in intrahepatic cholangiocarcinomas. Nat Genet 2013;45:1470-1473.

46 Sia D, Losic B, Moeini A, Cabellos L, Hao K, Revill K, Bonal D, Miltiadous O, Zhang Z, Hoshida Y, Cornella H, Castillo-Martin M, Pinyol R, Kasai Y, Roayaie S, Thung SN, Fuster J, Schwartz ME, Waxman S, Cordon-Cardo C, Schadt E, Mazzaferro V, Llovet JM: Massive parallel sequencing uncovers actionable FGFR2-PPHLN1 fusion and ARAF mutations in intrahepatic cholangiocarcinoma. Nat Commun 2015;6:6087.

47 Chan-On W, Nairismagi ML, Ong CK, Lim WK, Dima S, Pairojkul C, Lim KH, McPherson JR, Cutcutache I, Heng HL, Ooi L, Chung A, Chow P, Cheow PC, Lee SY, Choo SP, Tan IB, Duda D, Nastase A, Myint SS, Wong BH, Gan A, Rajasegaran V, Ng CC, Nagarajan S, Jusakul A, Zhang S, Vohra P, Yu W, Huang D, Sithithaworn P, Yongvanit P, Wongkham S, Khuntikeo N, Bhudhisawasdi V, Popescu I, Rozen SG, Tan P, Teh BT: Exome sequencing identifies distinct mutational patterns in liver fluke-related and non-infection-related bile duct cancers. Nat Genet 2013;45:1474-1478. 
48 Ong CK, Subimerb C, Pairojkul C, Wongkham S, Cutcutache I, Yu W, McPherson JR, Allen GE, Ng CC, Wong BH, Myint SS, Rajasegaran V, Heng HL, Gan A, Zang ZJ, Wu Y, Wu J, Lee MH, Huang D, Ong P, Chan-on W, Cao Y, Qian CN, Lim KH, Ooi A, Dykema K, Furge K, Kukongviriyapan V, Sripa B, Wongkham C, Yongvanit P, Futreal PA, Bhudhisawasdi V, Rozen S, Tan P, Teh BT: Exome sequencing of liver fluke-associated cholangiocarcinoma. Nat Genet 2012;44:690-693.

49 Jones S, Zhang X, Parsons DW, Lin JC, Leary RJ, Angenendt P, Mankoo P, Carter H, Kamiyama $\mathrm{H}$, Jimeno A, Hong SM, Fu B, Lin MT, Calhoun ES, Kamiyama M, Walter K, Nikolskaya T, Nikolsky Y, Hartigan J, Smith DR, Hidalgo M, Leach SD, Klein AP, Jaffee EM, Goggins M, Maitra A, Iacobuzio-Donahue C, Eshleman JR, Kern SE, Hruban RH, Karchin R, Papadopoulos N, Parmigiani G, Vogelstein B, Velculescu VE, Kinzler KW: Core signaling pathways in human pancreatic cancers revealed by global genomic analyses. Science 2008;321:1801-1806.

50 Lennerz JK, Stenzinger A: Allelic ratio of KRAS mutations in pancreatic cancer. Oncologist 2015;20:e8-e9.

51 Hingorani SR, Petricoin EF, Maitra A, Rajapakse V, King C, Jacobetz MA, Ross S, Conrads TP, Veenstra TD, Hitt BA, Kawaguchi $Y$, Johann D, Liotta LA, Crawford HC, Putt ME, Jacks T, Wright CV, Hruban RH, Lowy AM, Tuveson DA: Preinvasive and invasive ductal pancreatic cancer and its early detection in the mouse. Cancer Cell 2003;4:437-450.

52 Siveke JT, Einwachter H, Sipos B, LubesederMartellato C, Kloppel G, Schmid RM: Concomitant pancreatic activation of Kras(G12D) and Tgfa results in cystic papillary neoplasms reminiscent of human IPMN. Cancer Cell 2007;12:266-279.

53 Hruban RH, Wilentz RE, Kern SE: Genetic progression in the pancreatic ducts. Am J Pathol 2000;156:1821-1825.

54 Murphy SJ, Hart SN, Lima JF, Kipp BR, Klebig M, Winters JL, Szabo C, Zhang L, Eckloff BW, Petersen GM, Scherer SE, Gibbs RA, McWilliams RR, Vasmatzis G, Couch FJ: Genetic alterations associated with progression from pancreatic intraepithelial neoplasia to invasive pancreatic tumor. Gastroenterology 2013;145:1098-1109.e1.

55 Hruban RH, Maitra A, Kern SE, Goggins M: Precursors to pancreatic cancer. Gastroenterol Clin North Am 2007;36:831-849, vi.

56 Campbell PJ, Yachida S, Mudie LJ, Stephens PJ, Pleasance ED, Stebbings LA, Morsberger LA, Latimer C, McLaren S, Lin ML, McBride DJ, Varela I, Nik-Zainal SA, Leroy C, Jia M, Menzies A, Butler AP, Teague JW, Griffin CA, Burton J, Swerdlow H, Quail MA, Stratton MR, Iacobuzio-Donahue C, Futreal PA: The patterns and dynamics of genomic instability in metastatic pancreatic cancer. Nature 2010; 467:1109-1113.
57 Yachida S, Jones S, Bozic I, Antal T, Leary R, Fu B, Kamiyama M, Hruban RH, Eshleman JR, Nowak MA, Velculescu VE, Kinzler KW, Vogelstein B, Iacobuzio-Donahue CA: Distant metastasis occurs late during the genetic evolution of pancreatic cancer. Nature 2010; 467:1114-1117.

58 Biankin AV, Waddell N, Kassahn KS, Gingras MC, Muthuswamy LB, Johns AL, et al: Pancreatic cancer genomes reveal aberrations in axon guidance pathway genes. Nature 2012; 491:399-405.

59 Alexandrov LB, Nik-Zainal S, Wedge DC, Aparicio SA, Behjati S, Biankin AV, et al: Signatures of mutational processes in human cancer. Nature 2013;500:415-421.

60 Waddell N, Pajic M, Patch AM, Chang DK, Kassahn KS, Bailey P, et al: Whole genomes redefine the mutational landscape of pancreatic cancer. Nature 2015;518:495-501.

61 Witkiewicz AK, McMillan EA, Balaji U, Baek G, Lin WC, Mansour J, Mollaee M, Wagner KU, Koduru P, Yopp A, Choti MA, Yeo CJ, McCue P, White MA, Knudsen ES: Wholeexome sequencing of pancreatic cancer defines genetic diversity and therapeutic targets. Nat Commun 2015;6:6744.

62 Dal Molin M, Zhang M, de Wilde RF, Ottenhof NA, Rezaee N, Wolfgang CL, Blackford A, Vogelstein B, Kinzler KW, Papadopoulos N, Hruban RH, Maitra A, Wood LD: Very longterm survival following resection for pancreatic cancer is not explained by commonly mutated genes: results of whole-exome sequencing analysis. Clin Cancer Res 2015;21: 1944-1950.

63 Lievre A, Bachet JB, Boige V, Cayre A, Le Corre D, Buc E, Ychou M, Bouche O, Landi B, Louvet C, Andre T, Bibeau F, Diebold MD, Rougier P, Ducreux M, Tomasic G, Emile JF, Penault-Llorca F, Laurent-Puig P: KRAS mutations as an independent prognostic factor in patients with advanced colorectal cancer treated with cetuximab. J Clin Oncol 2008;26: 374-379.

64 Moroni M, Veronese S, Benvenuti S, Marrapese G, Sartore-Bianchi A, Di Nicolantonio F, Gambacorta M, Siena S, Bardelli A: Gene copy number for epidermal growth factor receptor (EGFR) and clinical response to antiEGFR treatment in colorectal cancer: a cohort study. Lancet Oncol 2005;6:279-286.

65 Amado RG, Wolf M, Peeters M, Van Cutsem E, Siena S, Freeman DJ, Juan T, Sikorski R, Suggs S, Radinsky R, Patterson SD, Chang DD: Wild-type KRAS is required for panitumumab efficacy in patients with metastatic colorectal cancer. J Clin Oncol 2008;26:16261634.

66 De Roock W, Claes B, Bernasconi D, De Schutter J, Biesmans B, Fountzilas G, et al: Effects of KRAS, BRAF, NRAS, and PIK3CA mutations on the efficacy of cetuximab plus chemotherapy in chemotherapy-refractory metastatic colorectal cancer: a retrospective consortium analysis. Lancet Oncol 2010;11: 753-762.
67 Venook AP, Niedzwiecki D, Innocenti F, Fruth B, Greene V, O'Neil BH, Shaw JE, Atkins JN, Horvath LE, Polite BN, Meyerhardt JA, O'Reilly EM, Goldberg RM, Hochster HS, Blanke CD, Schilsky RL, Mayer RJ, Bertagnolli MM, Lenz HJ: Impact of primary $\left(1^{\circ}\right)$ tumor location on overall survival (OS) and progression-free survival (PFS) in patients with metastatic colorectal cancer (mCRC): analysis of CALGB/SWOG 80405 (Alliance). Proc Am Soc Clin Oncol 2016;34 (abstract 3504).

68 Bang YJ, Van Cutsem E, Feyereislova A, Chung HC, Shen L, Sawaki A, Lordick F, Ohtsu A, Omuro Y, Satoh T, Aprile G, Kulikov E, Hill J, Lehle M, Ruschoff J, Kang YK; ToGA Trial Investigators: Trastuzumab in combination with chemotherapy versus chemotherapy alone for treatment of HER2-positive advanced gastric or gastro-oesophageal junction cancer (ToGA): a phase 3, open-label, randomised controlled trial. Lancet 2010;376: 687-697.

69 Pfarr N, Stenzinger A, Penzel R, Warth A, Dienemann H, Schirmacher P, Weichert W, Endris V: High-throughput diagnostic profiling of clinically actionable gene fusions in lung cancer. Genes Chromosomes Cancer 2016;55:30-44

70 Klauschen F, Heim D, Stenzinger A: Histological tumor typing in the age of molecular profiling. Pathol Res Pract 2015;211:897-900.

71 Klauschen F, Andreeff M, Keilholz U, Dietel $\mathrm{M}$, Stenzinger A: The combinatorial complexity of cancer precision medicine. Oncoscience 2014;1:504-509.

72 Malapelle U, Vigliar E, Sgariglia R, Bellevicine C, Colarossi L, Vitale D, Pallante P, Troncone $\mathrm{G}$ : Ion torrent next-generation sequencing for routine identification of clinically relevant mutations in colorectal cancer patients. J Clin Pathol 2015;68:64-68.

73 Kircher SM, Mohindra N, Nimeiri H: Cost estimates and economic implications of expanded RAS testing in metastatic colorectal cancer. Oncologist 2015;20:14-18.

74 Kordes M, Roring M, Heining C, Braun S, Hutter B, Richter D, Georg C, Scholl C, Groschel S, Roth W, Rosenwald A, Geissinger E, von Kalle C, Jager D, Brors B, Weichert W, Grullich C, Glimm H, Brummer T, Frohling $S$ : Cooperation of BRAF and mutant HRAS in histiocytic sarcoma provides new insights into oncogenic BRAF signaling. Leukemia 2016;30:937-946.

75 Nowell PC: The clonal evolution of tumor cell populations. Science 1976;194:23-28.

76 Campbell PJ, Pleasance ED, Stephens PJ, Dicks E, Rance R, Goodhead I, Follows GA, Green AR, Futreal PA, Stratton MR: Subclonal phylogenetic structures in cancer revealed by ultra-deep sequencing. Proc Natl Acad Sci USA 2008;105:13081-13086. 
77 Gerlinger M, Rowan AJ, Horswell S, Larkin J, Endesfelder D, Gronroos E, Martinez P, Matthews N, Stewart A, Tarpey P, Varela I, Phillimore B, Begum S, McDonald NQ, Butler A, Jones D, Raine K, Latimer C, Santos CR, Nohadani M, Eklund AC, Spencer-Dene B, Clark G, Pickering L, Stamp G, Gore M, Szallasi Z, Downward J, Futreal PA, Swanton C: Intratumor heterogeneity and branched evolution revealed by multiregion sequencing. $\mathrm{N}$ Engl J Med 2012;366:883-892.

78 Jamal-Hanjani M, Quezada SA, Larkin J, Swanton C: Translational implications of tumor heterogeneity. Clin Cancer Res 2015;21: 1258-1266.

79 Burrell RA, Swanton C: Tumour heterogeneity and the evolution of polyclonal drug resistance. Mol Oncol 2014;8:1095-1111.

80 Schmitt MW, Loeb LA, Salk JJ: The influence of subclonal resistance mutations on targeted cancer therapy. Nat Rev Clin Oncol 2016;13: 335-347.

81 Naxerova K, Brachtel E, Salk JJ, Seese AM, Power K, Abbasi B, Snuderl M, Chiang S, Kasif S, Jain RK: Hypermutable DNA chronicles the evolution of human colon cancer. Proc Natl Acad Sci USA 2014;111:E1889-E1898.

82 Ross-Innes CS, Becq J, Warren A, Cheetham RK, Northen H, O'Donovan M, Malhotra S, di Pietro M, Ivakhno S, He M, Weaver JM, Lynch AG, Kingsbury Z, Ross M, Humphray S, Bentley D, Fitzgerald RC; Oesophageal Cancer Clinical and Molecular Molecular Stratification Study Group: Whole-genome sequencing provides new insights into the clonal architecture of Barrett's esophagus and esophageal adenocarcinoma. Nat Genet 2015; 47:1038-1046.

83 Stachler MD, Taylor-Weiner A, Peng S, McKenna A, Agoston AT, Odze RD, Davison JM, Nason KS, Loda M, Leshchiner I, Stewart C, Stojanov P, Seepo S, Lawrence MS, FerrerTorres D, Lin J, Chang AC, Gabriel SB, Lander ES, Beer DG, Getz G, Carter SL, Bass AJ: Paired exome analysis of Barrett's esophagus and adenocarcinoma. Nat Genet 2015;47: 1047-1055.

84 Ruzzenente A, Fassan M, Conci S, Simbolo M, Lawlor RT, Pedrazzani C, Capelli P, D’Onofrio M, Iacono C, Scarpa A, Guglielmi A: Cholangiocarcinoma heterogeneity revealed by multigene mutational profiling: clinical and prognostic relevance in surgically resected patients. Ann Surg Oncol 2016;23:1699-1707.

85 Xue R, Li R, Guo H, Guo L, Su Z, Ni X, Qi L, Zhang T, Li Q, Zhang Z, Xie XS, Bai F, Zhang $\mathrm{N}$ : Variable extent of intra-tumor heterogeneity revealed by genomic sequencing of multiple lesions in patients with hepatocellular carcinoma. Gastroenterology 2016;150: 998-1008.

86 Friemel J, Rechsteiner M, Frick L, Bohm F, Struckmann K, Egger M, Moch H, Heikenwalder M, Weber A: Intratumor heterogeneity in hepatocellular carcinoma. Clin Cancer Res 2015;21:1951-1961.
87 Hyman DM, Puzanov I, Subbiah V, Faris JE, Chau I, Blay JY, Wolf J, Raje NS, Diamond EL, Hollebecque A, Gervais R, Elez-Fernandez ME, Italiano A, Hofheinz RD, Hidalgo M, Chan E, Schuler M, Lasserre SF, Makrutzki M, Sirzen F, Veronese ML, Tabernero J, Baselga $\mathrm{J}$ : Vemurafenib in multiple nonmelanoma cancers with BRAF V600 mutations. N Engl J Med 2015;373:726-736.

88 Prahallad A, Sun C, Huang S, Di Nicolantonio F, Salazar R, Zecchin D, Beijersbergen RL, Bardelli A, Bernards R: Unresponsiveness of colon cancer to BRAF(V600E) inhibition through feedback activation of EGFR. Nature 2012;483:100-103.

89 Stenzinger A, Weichert W, Lennerz JK, Klauschen F: Basket trials: just the end of the first quarter. J Clin Oncol 2015;33:2823-2824.

90 Pfarr N, Sinn HP, Klauschen F, Flechtenmacher C, Bockmayr M, Ridinger $\mathrm{K}$, von Winterfeld M, Warth A, Lorenz K, Budczies J, Penzel R, Lennerz JK, Endris V, Weichert W, Stenzinger A: Mutations in genes encoding PI3K-AKT and MAPK signaling define anogenital papillary hidradenoma. Genes Chromosomes Cancer 2016;55:113-119.

91 Jesinghaus M, Wolf T, Pfarr N, Muckenhuber A, Ahadova A, Warth A, Goeppert B, Sers C, Kloor M, Endris V, Stenzinger A, Weichert W: Distinctive spatiotemporal stability of somatic mutations in metastasized microsatellite-stable colorectal cancer. Am J Surg Pathol 2015;39:1140-1147.

92 Brannon AR, Vakiani E, Sylvester BE, Scott SN, McDermott G, Shah RH, Kania K, Viale A, Oschwald DM, Vacic V, Emde AK, Cercek A, Yaeger R, Kemeny NE, Saltz LB, Shia J, D’Angelica MI, Weiser MR, Solit DB, Berger MF: Comparative sequencing analysis reveals high genomic concordance between matched primary and metastatic colorectal cancer lesions. Genome Biol 2014;15:454.

93 Wagle N, Emery C, Berger MF, Davis MJ, Sawyer A, Pochanard P, Kehoe SM, Johannessen CM, Macconaill LE, Hahn WC, Meyerson M, Garraway LA: Dissecting therapeutic resistance to RAF inhibition in melanoma by tumor genomic profiling. J Clin Oncol 2011; 29:3085-3096.

94 Lander ES, Linton LM, Birren B, Nusbaum C, Zody MC, Baldwin J, et al: Initial sequencing and analysis of the human genome. Nature 2001;409:860-921.

95 Weichert W, Schewe C, Lehmann A, Sers C, Denkert C, Budczies J, Stenzinger A, Joos H, Landt O, Heiser V, Rocken C, Dietel M: KRAS genotyping of paraffin-embedded colorectal cancer tissue in routine diagnostics: comparison of methods and impact of histology. J Mol Diagn 2010;12:35-42.

96 Jesinghaus M, Pfarr N, Kloor M, Endris V, Tavernar L, Muckenhuber A, von Knebel Doeberitz M, Penzel R, Weichert W, Stenzinger A: Genetic heterogeneity in synchronous colorectal cancers impacts genotyping approaches and therapeutic strategies. Genes Chromosomes Cancer 2016;55:268-277.
97 Stenzinger A, Pfarr N, Penzel R, Wolf T, Schirmacher P, Endris V, Weichert W: Semiconductor-based sequencing of formalin-fixed, paraffin-embedded colorectal cancer samples. Oncologist 2015;20:e10-e11.

98 Kriegsmann M, Endris V, Wolf T, Pfarr N, Stenzinger A, Loibl S, Denkert C, Schneeweiss A, Budczies J, Sinn P, Weichert W: Mutational profiles in triple-negative breast cancer defined by ultradeep multigene sequencing show high rates of PI3K pathway alterations and clinically relevant entity subgroup specific differences. Oncotarget 2014; 5:9952-9965.

99 Stenzinger A, Endris V, Pfarr N, Andrulis M, Johrens K, Klauschen F, Siebolts U, Wolf T, Koch PS, Schulz M, Hartschuh W, Goerdt S, Lennerz JK, Wickenhauser C, Klapper W, Anagnostopoulos I, Weichert W: Targeted ultra-deep sequencing reveals recurrent and mutually exclusive mutations of cancer genes in blastic plasmacytoid dendritic cell neoplasm. Oncotarget 2014;5:6404-6413.

100 Leung ML, Wang Y, Waters J, Navin NE: SNES: single nucleus exome sequencing. Genome Biol 2015;16:55.

101 Van Allen EM, Wagle N, Stojanov P, Perrin DL, Cibulskis K, Marlow S, Jane-Valbuena J, Friedrich DC, Kryukov G, Carter SL, McKenna A, Sivachenko A, Rosenberg M, Kiezun A, Voet D, Lawrence M, Lichtenstein LT, Gentry JG, Huang FW, Fostel J, Farlow D, Barbie D, Gandhi L, Lander ES, Gray SW, Joffe S, Janne P, Garber J, MacConaill L, Lindeman N, Rollins B, Kantoff P, Fisher SA, Gabriel S, Getz G, Garraway LA: Wholeexome sequencing and clinical interpretation of formalin-fixed, paraffin-embedded tumor samples to guide precision cancer medicine. Nat Med 2014;20:682-688.

102 Collins FS, Varmus H: A new initiative on precision medicine. N Engl J Med 2015;372: 793-795.

103 Endris V, Penzel R, Warth A, Muckenhuber A, Schirmacher P, Stenzinger A, Weichert W: Molecular diagnostic profiling of lung cancer specimens with a semiconductorbased massive parallel sequencing approach: feasibility, costs, and performance compared with conventional sequencing. J Mol Diagn 2013;15:765-775.

104 Budczies J PN, Stenzinger A, Treue D, Endris $\mathrm{V}$, Ismaeel $\mathrm{F}$, Bangemann $\mathrm{N}$, Blohmer JU, Dietel M, Loibl S, Klauschen F, Weichert W, Denkert C: Ioncopy: a novel method for calling copy number alterations in amplicon sequencing data including significance assessment. Oncotarget 2016;7:13236-13247.

105 Zheng Z, Liebers M, Zhelyazkova B, Cao Y, Panditi D, Lynch KD, Chen J, Robinson HE, Shim HS, Chmielecki J, Pao W, Engelman JA, Iafrate AJ, Le LP: Anchored multiplex PCR for targeted next-generation sequencing. Nat Med 2014;20:1479-1484. 
106 Endris V, Stenzinger A, Pfarr N, Penzel R, Möbs M, Lenze D, Darb-Esfahani S, Hummel M, Merkelbach-Bruse S, Jung A, Lehmann U, Kreipe H, Kirchner T, Büttner R, Jochum W, Höfler G, Dietel M, Weichert W, Schirmacher P: NGS-based BRCA1/2 mutation testing of high-grade serous ovarian cancer tissue: results and conclusions of the first international round robin trial. Virchows Arch 2016;468:697-705.

107 Mullard A: NCI-MATCH trial pushes cancer umbrella trial paradigm. Nat Rev Drug Discov 2015;14:513-515.

108 Kopetz S, Desai J, Chan E, Hecht JR, O’Dwyer PJ, Maru D, Morris V, Janku F, Dasari A, Chung W, Issa JP, Gibbs P, James B, Powis G, Nolop KB, Bhattacharya S, Saltz L: Phase II pilot study of vemurafenib in patients with metastatic Braf-mutated colorectal cancer. J Clin Oncol 2015;33:4032-4038.

109 Corcoran RB, Ebi H, Turke AB, Coffee EM, Nishino M, Cogdill AP, Brown RD, Della Pelle P, Dias-Santagata D, Hung KE, Flaherty KT, Piris A, Wargo JA, Settleman J, Mino-Kenudson M, Engelman JA: EGFRmediated re-activation of MAPK signaling contributes to insensitivity of BRAF mutant colorectal cancers to RAF inhibition with vemurafenib. Cancer Discov 2012;2:227-235.

110 Fakih MG: Metastatic colorectal cancer: current state and future directions. J Clin Oncol 2015;33:1809-1824.

111 Marien KM, Croons V, Martinet W, De Loof H, Ung C, Waelput W, Scherer SJ, Kockx MM, De Meyer GR: Predictive tissue biomarkers for bevacizumab-containing therapy in metastatic colorectal cancer: an update. Expert Rev Mol Diagn 2015;15:399-414.

112 Xiao Y, Freeman GJ: The microsatellite instable subset of colorectal cancer is a particularly good candidate for checkpoint blockade immunotherapy. Cancer Discov 2015;5: $16-18$.

113 Stenzinger A, Pfarr N, Endris V, Penzel R, Jansen L, Wolf T, Herpel E, Warth A, Klauschen F, Kloor M, Roth W, Blaker H, Chang-Claude J, Brenner H, Hoffmeister M, Weichert W: Mutations in pole and survival of colorectal cancer patients - link to disease stage and treatment. Cancer Med 2014;3: 1527-1538.

114 Briggs S, Tomlinson I: Germline and somatic polymerase epsilon and delta mutations define a new class of hypermutated colorectal and endometrial cancers. J Pathol 2013; 230:148-153

115 Stadler ZK, Battaglin F, Middha S, Hechtman JF, Tran C, Cercek A, Yaeger R, Segal NH, Varghese AM, Reidy-Lagunes DL, Kemeny NE, Salo-Mullen EE, Ashraf A, Weiser MR, Garcia-Aguilar J, Robson ME, Offit K, Arcila ME, Berger MF, Shia J, Solit DB, Saltz LB: Reliable detection of mismatch repair deficiency in colorectal cancers using mutational load in next-generation sequencing panels. J Clin Oncol 2016;34:2141-2147.
116 Shah MA: Update on metastatic gastric and esophageal cancers. J Clin Oncol 2015;33: 1760-1769.

117 Iveson T, Donehower RC, Davidenko I, Tjulandin S, Deptala A, Harrison M, Nirni S, Lakshmaiah K, Thomas A, Jiang Y, Zhu M, Tang R, Anderson A, Dubey S, Oliner KS, Loh E: Rilotumumab in combination with epirubicin, cisplatin, and capecitabine as first-line treatment for gastric or oesophagogastric junction adenocarcinoma: an openlabel, dose de-escalation phase $1 \mathrm{~b}$ study and a double-blind, randomised phase 2 study. Lancet Oncol 2014;15:1007-1018.

118 Javle M, Smyth EC, Chau I: Ramucirumab: successfully targeting angiogenesis in gastric cancer. Clin Cancer Res 2014;20:5875-5881.

119 Woo J, Cohen SA, Grim JE: Targeted therapy in gastroesophageal cancers: past, present and future. Gastroenterol Rep (Oxf) 2015;3: 316-329.

120 Muro K, Bang YJ, Shankaran V, Geva R, Catenacci DVT, Gupta S, Eder JP, Berger R, Gonzalez EJ, Ray A, Dolled-Filhart $\mathrm{M}$, Emancipator K, Pathiraja K, Lunceford JK, Cheng JD, Koshiji M, Chung HC: Relationship between PD-L1 expression and clinical outcomes in patients (Pts) with advanced gastric cancer treated with the anti-PD-1 monoclonal antibody pembrolizumab (Pembro; MK-3475) in KEYNOTE-012. J Clin Oncol 2015;33:3.

121 Le DT, Uram JN, Wang H, Bartlett BR, Kemberling $\mathrm{H}$, Eyring $\mathrm{AD}$, Skora $\mathrm{AD}$, Luber BS, Azad NS, Laheru D, Biedrzycki B, Donehower RC, Zaheer A, Fisher GA, Crocenzi TS, Lee JJ, Duffy SM, Goldberg RM, de la Chapelle A, Koshiji M, Bhaijee F, Huebner T, Hruban RH, Wood LD, Cuka N, Pardoll DM, Papadopoulos N, Kinzler KW, Zhou S, Cornish TC, Taube JM, Anders RA, Eshleman JR, Vogelstein B, Diaz LA Jr: PD-1 blockade in tumors with mismatch-repair deficiency. N Engl J Med 2015;372:25092520.

122 Llovet JM, Hernandez-Gea V: Hepatocellular carcinoma: Reasons for phase III failure and novel perspectives on trial design. Clin Cancer Res 2014;20:2072-2079.

123 Zucman-Rossi J, Villanueva A, Nault JC, Llovet JM: Genetic landscape and biomarkers of hepatocellular carcinoma. Gastroenterology 2015;149:1226-1239 e1224.

124 Rimassa L, Porta C, Borbath I, Daniele B, Salvagni S, Van Laethem JL, Van Vlieberghe H, Trojan J, Kolligs FT, Weiss A, Barahona N, Gasbarrini A, Lencioni M, Pande AU, Lamar M, Chen YP, Schwartz BE, Abbadessa G, Santoro A: Tivantinib (ARQ 197) versus placebo in patients (Pts) with hepatocellular carcinoma (HCC) who failed one systemic therapy: results of a randomized controlled phase II trial (RCT). J Clin Oncol 2012;30:4006.
125 Hagel M, Miduturu C, Sheets M, Rubin N, Weng W, Stransky N, Bifulco N, Kim JL, Hodous B, Brooijmans N, Shutes A, Winter C, Lengauer C, Kohl NE, Guzi T: First selective small molecule inhibitor of FGFR4 for the treatment of hepatocellular carcinomas with an activated FGFR4 signaling pathway. Cancer Discov 2015;5:424-437.

126 Goyal L, Saha SK, Liu LY, Siravegna G, Leshchiner I, Ahronian LG, Lennerz JK, Vu P, Deshpande V, Kambadakone A, Mussolin B, Reyes S, Henderson L, Sun JE, Van Seventer EE, Gurski JM, Baltschukat S, SchacherEngstler B, Barys L, Stamm C, Furet P, Ryan DP, Stone JR, Iafrate AJ, Getz G, Graus Porta D, Tiedt R, Bardelli A, Juric D, Corcoran RB, Bardeesy N, Zhu AX: Polyclonal secondary FGFR2 mutations drive acquired resistance to FGFR inhibition in patients with FGFR2 fusion-positive cholangiocarcinoma. Cancer Discov 2016, doi: 10.1158/21598290.CD-16-1000, Epub ahead of print.

127 Suder A, Ang JE, Kyle F, Harris D, Rudman S, Kristeleit R, Solca F, Uttenreuther-Fischer M, Pemberton K, Pelling K, Schnell D, de Bono J, Spicer J: A phase I study of daily afatinib, an irreversible ErbB family blocker, in combination with weekly paclitaxel in patients with advanced solid tumours. Eur J Cancer 2015;51:2275-2284.

128 Javle M, Churi C, Kang HC, Shroff R, Janku F, Surapaneni R, Zuo M, Barrera C, Alshamsi H, Krishnan S, Mishra L, Wolff RA, Kaseb AO, Thomas MB, Siegel AB: Her2/neu-directed therapy for biliary tract cancer. J Hematol Oncol 2015;8:58.

129 Knudsen ES, O’Reilly EM, Brody JR, Witkiewicz AK: Genetic diversity of pancreatic ductal adenocarcinoma and opportunities for precision medicine. Gastroenterology 2016;150:48-63.

130 Philip PA, Lutz MP: Targeting epidermal growth factor receptor-related signaling pathways in pancreatic cancer. Pancreas 2015;44:1046-1052.

131 Oza AM, Cibula D, Benzaquen AO, Poole C, Mathijssen RH, Sonke GS, Colombo N, Spacek J, Vuylsteke P, Hirte H, Mahner S, Plante M, Schmalfeldt B, Mackay H, Rowbottom J, Lowe ES, Dougherty B, Barrett JC, Friedlander M: Olaparib combined with chemotherapy for recurrent platinum-sensitive ovarian cancer: a randomised phase 2 trial. Lancet Oncol 2015; 16:87-97.

132 Kaufman B, Shapira-Frommer R, Schmutzler RK, Audeh MW, Friedlander M, Balmana J, Mitchell G, Fried G, Stemmer SM, Hubert A, Rosengarten O, Steiner M, Loman N, Bowen K, Fielding A, Domchek SM: Olaparib monotherapy in patients with advanced cancer and a germline BRCA1/2 mutation. J Clin Oncol 2015;33: 244-250. 
133 Budczies J, Bockmayr M, Denkert C, Klauschen F, Gröschel S, Darb-Esfahani S, Pfarr N, Leichsenring J, Onozato ML, Lennerz JK, Dietel M, Fröhling S, Schirmacher P, Iafrate AJ, Weichert W, Stenzinger A: Pan-cancer analysis of copy number changes in programmed death-ligand 1 (PD-L1, CD274) - associations with gene expression, mutational load, and survival. Genes Chromosomes Cancer 2016;55:626639.

134 Gröschel S, Bommer M, Hutter B, Budczies $\mathrm{J}$, Bonekamp D, Heining C, Horak P, Fröhlich M, Uhrig S, Hübschmann D, Geörg C, Richter D, Pfarr N, Pfütze K, Wolf S,
Schirmacher P, Jäger D, von Kalle C, Brors B, Glimm H, Weichert W, Stenzinger A, Fröhling S: Integration of genomics and histology revises diagnosis and enables effective therapy of refractory cancer of unknown primary with PDL1 amplification. Cold Spring Harb Mol Case Stud 2016;2:a01180.

135 Shin DS, Zaretsky JM, Escuin-Ordinas H, Garcia-Diaz A, Hu-Lieskovan S, Kalbasi A, Grasso CS, Hugo W, Sandoval S, Torrejon DY, Palaskas N, Abril Rodriguez G, Parisi G, Azhdam A, Chmielowski B, Cherry G, Seja E, Berent-Maoz B, Shintaku IP, Le DT, Pardoll DM, Diaz LA, Tumeh PC, Graeber TG, Lo RS, Comin-Anduix B, Ribas A: Primary resistance to $\mathrm{PD}-1$ blockade mediated by JAK1/2 mutations. Cancer Discov 2016, pii: CD-16-1223, Epub ahead of print.

136 Zaretsky JM, Garcia-Diaz A, Shin DS, Escuin-Ordinas H, Hugo W, Hu-Lieskovan S, Torrejon DY, Abril-Rodriguez G, Sandoval S, Barthly L, Saco J, Homet Moreno B, Mezzadra R, Chmielowski B, Ruchalski K, Shintaku IP, Sanchez PJ, Puig-Saus C, Cherry G, Seja E, Kong X, Pang J, Berent-Maoz B, Comin-Anduix B, Graeber TG, Tumeh PC, Schumacher TN, Lo RS, Ribas A: Mutations associated with acquired resistance to PD-1 blockade in melanoma. N Engl J Med 2016;375:819-829. 